The University of Akron

IdeaExchange@UAkron

Akron Law Review

Akron Law Journals

February 2018

\title{
Dissecting the ABA Texas Capital Punishment Assessment Report of 2013: Death and Texas, a Surprising Improvement
}

Patrick S. Metze

Please take a moment to share how this work helps you through this survey. Your feedback will be important as we plan further development of our repository.

Follow this and additional works at: http://ideaexchange.uakron.edu/akronlawreview

Part of the Criminal Law Commons, and the Criminal Procedure Commons

\section{Recommended Citation}

Metze, Patrick S. (2017) "Dissecting the ABA Texas Capital Punishment Assessment Report of 2013: Death and Texas, a Surprising Improvement," Akron Law Review: Vol. 51 : Iss. 2 , Article 1.

Available at: http://ideaexchange.uakron.edu/akronlawreview/vol51/iss2/1

This Article is brought to you for free and open access by Akron Law Journals at IdeaExchange@UAkron, the institutional repository of The University of Akron in Akron, Ohio, USA. It has been accepted for inclusion in Akron Law Review by an authorized administrator of IdeaExchange@UAkron. For more information, please contactmjon@uakron.edu, uapress@uakron.edu. 


\title{
Dissecting the ABA Texas Capital Punishment ASSESSMENT REPORT OF 2013: DEATH AND TEXAS, A SURPRISING IMPROVEMENT
}

\author{
Patrick S. Metze*
}

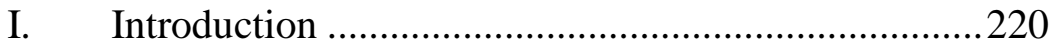

II. Evaluating Fairness and Accuracy in State Death

Penalty Systems: The Texas Capital Punishment Assessment Report (2013)........................................... 221

A. Identification and Interrogation .........................2222

1. Interrogations ................................................ 223

2. Eyewitness Identification................................224

3. Accountability ................................................225

4. Informants .......................................................226

5. Forensics .......................................................222

B. Collection, Preservation, DNA Testing, and Other

Evidence.........................................................2227

C. Crime Labs and Medical Examiners...................230

D. Prosecution......................................................233

1. Recommendation \#1: Prosecutorial Discretion.....................................................2234

2. Recommendation \#2: Evidentiary Concerns . 235

3. Recommendation \#3: Discovery ....................236

4. Recommendations \#4, \#5, and \#6.................. 236

5. Approaching Prosecutorial Misconduct .........2238

E. Defense ......................................................... 239

F. The Direct Appeal Process and Proportionality

Review ...............................................................2241

G. State Habeas Corpus Proceedings......................242

* Patrick S. Metze is a Professor of Law and Director of the Criminal Clinics at Texas Tech University School of Law. B.A., Texas Tech University 1970; J.D., The University of Houston 1973. I want to thank Rasha Zeyadeh, my research assistant, for her assistance and never failing positive attitude about life and work. My wish for her, as she studies for the Bar this summer, is a long, prosperous, happy life in the law. 


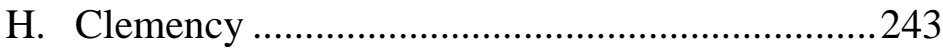

I. Capital Jury Instructions ....................................2246

J. Judicial Independence and Vigilance..................248

K. Racial and Ethnic Minorities .............................2250

L. Intellectual Disability and Mental Illness ...........251

III. Conclusion ................................................................ 254

\section{INTRODUCTION}

What good am I if I'm like all the rest If I just turn away, when I see how you're dressed

If I shut myself off so I can't hear you cry What good am I?

What good am I if I know and don't do If I see and don't say, if I look right through you

If I turn a deaf ear to the thunderin' sky What good am I?

What good am I while you softly weep And I hear in my head what you say in your sleep And I freeze in the moment like the rest who don't try

What good am I?

What good am I then to others and me If I've had every chance and yet still fail to see If my hands are tied must I not wonder within Who tied them and why and where must I have been?

What good am I if I say foolish things And I laugh in the face of what sorrow brings And I just turn my back while you silently die What good am I? ${ }^{1}$ 


\section{Evaluating Fairness AND ACCURACy in StAte DeAth PENALty} SYSTEMS: THE TEXAS CAPITAL PUNISHMENT ASSESSMENT REPORT

(2013)

On September 2013, the American Bar Association (ABA) issued: Evaluating Fairness and Accuracy in State Death Penalty Systems: The Texas Capital Punishment Assessment Report - An Analysis of Texas's Death Penalty Laws, Procedures and Practices (ABA Report). ${ }^{2}$ This 517page report was produced by the ABA's Death Penalty Due Process Review Project. ${ }^{3}$ At the beginning of the ABA Report, the Texas Capital Punishment Assessment Team ${ }^{4}$ listed the "checks and balances" necessary in the Texas death penalty scheme "to ensure fairness in selection of offenders to receive the death penalty, reduce to the extent possible the risk of executing the innocent, and preserve public confidence in the administration of criminal justice." ${ }^{5}$ Prior to this report, the ABA had issued 11 similar reports in other death penalty jurisdictions. ${ }^{6}$

The ABA Report highlighted the inadequacies of the Texas Capital Punishment System and suggested changes. There were 12 separate categories for improvement: (1) identification and interrogation; (2) collection, preservation, DNA testing, and other evidence; (3) crime labs and medical examiners; (4) prosecution; (5) defense; (6) direct appeal and proportionality review; (7) habeas corpus; (8) clemency; (9) jury instructions (10) judicial independence and vigilance; (11) race minorities; and (12) intellectual disability and mental illness. ${ }^{7}$

Following the release of the ABA Report, Texas has shown improvement in the death penalty process through legislative measures, prosecutorial training and accountability, financial support, interrogation recording, and an exoneration review commission, to name a few. This Article will explore what Texas has and has not done since the ABA

2. Am. Bar Ass'n, Evaluating Fairness and Accuracy in State Death Penalty Systems: The Texas Capital Punishment Assessment Report - An Analysis of Texas's Death Penalty Laws, Procedures and Practices 3 (2013), http://www.americanbar.org/content/dam/aba/administrative/ death_penalty_moratorium/tx_complete_report.authcheckdam.pdf [http://perma.cc/QX4D-4G2W].

3. Id.

4. The ABA Report acknowledged the project attorneys, interns, volunteers, clerks, and others within the American Bar Association Section of Individual Rights and Responsibilities for their work on the report, as well as the members of the Texas Capital Punishment Assessment Team, Professor Jennifer Laurin, Ron Breaux, Paul Coggins, Dean Royal Furgeson, The Honorable Deborah Hankinson, Professor Ana M. Otero, Charles T. Terrell, and Governor Mark White. Id.

5. Id. at iii.

6. Id. at i. Those 11 states were Alabama, Arizona, Florida, Georgia, Indiana, Kentucky, Missouri, Ohio, Pennsylvania, Tennessee, and Virginia.

7. Id. at ii. Each of these categories for improvement are developed in their own chapters within the ABA Report and likewise are addressed by their own corresponding sections below. 
Report to further the Report's stated purposes. Finally, I list my thoughts as to how our maturing society is evolving on this most important dilemma - should we laugh in the face of what sorrow brings, turning our back while you silently die, while asking, what good am I? ${ }^{8}$

\section{A. Identification and Interrogation}

The ABA Report identified several issues pertaining to law enforcement identification and interrogation procedures. ${ }^{9}$ Of 416 murder exonerations nationwide, $27 \%$ contained an eyewitness misidentification and $25 \%$ contained a false confession. ${ }^{10}$ Under this ABA identified category, there were nine recommendations made by the ABA Report. ${ }^{11}$ At the time of the report, Texas was in compliance with three of the recommendations, ${ }^{12}$ in partial compliance with an additional three recommendations, ${ }^{13}$ not in compliance with one recommendation, ${ }^{14}$ and with two of the recommendations compliance could not be determined because of insufficient information. ${ }^{15}$

The most significant development in this area since the ABA Report was the work of The Timothy Cole Exoneration Review Commission (Commission). ${ }^{16}$ The Commission released a 59-page report in December

8. See DYLAN, supra note 1.

9. Am. Bar Ass'n, supra note 2 at 27.

10. Id. (citing Samuel R. Gross et al., Exonerations in the United States, 1989-2012-Report by the National Registry of Exonerations 18 (2012)).

11. Id. at 35-54.

12. Id. at xxi-xxii. Recommendations \#2, \#3, and \#6 were in compliance. Id. at 42 (showing that Tex. Code CRIM. PRoc. ANN. art. $38.20 \S 3(\mathrm{~b})$ requires training for law enforcement and prosecutors on lineups and interviewing techniques); id. at 43 (explaining that law enforcement and prosecutors should update lineup policy according to TEX. CODE CRIM. PROC. ANN. art. 38.20 § 4); and $i d$. at 48 (explaining that qualified experts on eyewitness testimony can testify pretrial and at trial).

13. Id. at xxi-xxii. Recommendations \#1, \#4, and \#5 were in partial compliance. Id. at 35 (explaining to follow the ABA's Best Practices for Promoting the Accuracy of Eyewitness Identification Procedures). Id. at 43 (explaining that video or audio recording should be conducted during the entire custodial interrogation process). Id. at 46 (explaining that there should be provided adequate funding for identification and interrogations policies).

14. Id. at xxi-xxii. Recommendation \#7 was not in compliance. See id. at 49 (explaining that jury instructions should be given on factors to consider in "gauging lineup accuracy" and in crossracial identification situations).

15. Id. at xxi-xxii. Insufficient information was available for the ABA Report to determine compliance with Recommendations \#8 and \#9. See id. at 52. Recommendation \#8 included every law enforcement agency should train and discipline personnel to ensure compliance and Recommendation \#9 stated citizens and investigators should be able to report misconduct in investigations. Id.

16. See TeX. Code Crim. Proc. AnN. art. 43.27 (LEXIS through 2017 Sess.), which created the Timothy Cole Exoneration Review Commission.

Tim Cole, who was wrongfully accused of sexually assaulting a Texas Tech woman in 
2016 calling for the electronic recording of all felon interrogations-from start to finish—as well as changes to eyewitness identification procedures, the use of jailhouse informants, and improved forensic practices. ${ }^{17}$

\section{Interrogations}

The Commission received surveys from only 850 of over 1,900 law enforcement agencies in Texas regarding electronically recorded interrogations, showing that just over two-thirds of those responding presently are recording their interrogations. ${ }^{18}$ Judges, prosecutors, and defense attorneys that responded to the Commission were in overwhelming agreement that the recording of interrogations is a favorable mechanism. ${ }^{19}$ However, the recording of interrogations is mandatory in only 21 states and the District of Columbia, with a mere 14 states requiring recording for felony-related offenses, and this does not include Texas. ${ }^{20}$ The Commission recommended a statute that would require either audio or audiovisual electronic recording of interrogations in all felony cases, starting from when the suspect enters the room, enforced by the courts by a rebuttable presumption that unrecorded statements are inadmissible. ${ }^{21}$

As of May 24, 2017, a Bill has been approved by both the Senate and House in Texas during the 85th Legislative Session and has been sent to the Governor. ${ }^{22}$ The Bill requires electronic recording of custodial interrogations in a list of serious felonies, including capital murder, requiring the recording from the "time the person being interrogated

1985, maintained his innocence up until his death behind bars in 1999. He was sentenced to 25 years in prison after the victim wrongfully identified Cole as the rapist after looking at a photo spread administered by the Lubbock Police Department. It wasn't until years later when Jerry Wayne Johnson confessed to the crime that Cole's name was cleared through DNA testing. Cole became the first person posthumously exonerated in Texas by then-Gov. Rick Perry in 2010.

Sara Rafique, Tim Cole Commission Offers Recommendations to Reduce Wrongful Convictions, LuBBocK AVAlanche-JouRnal (Jan. 7, 2017), http:/lubbockonline.com/local/2017-01-07/timcole-commission-offers-recommendations-reduce-wrongful-convictions [http://perma.cc/V3PGZBYQ].

17. See Timothy Cole Exoneration Review Comm'n, Final Report to Texas Governor Greg Abbott, Texas Legislature and Texas Judicial Council (2016).

18. Id. at 13. According to the U.S. Bureau of Justice Statistics' Census of State and Local Law Enforcement Agencies, Texas had 1,913 law enforcement agencies in 2008. Brian Reaves, Census of State and Local Law Enforcement Agencies, 2008, U.S. DEP'T OF JusTiCE (July 2011), https://www.bjs.gov/content/pub/pdf/csllea08.pdf [http://perma.cc/7KFF-NKUS].

19. Timothy Cole Exoneration Review Comm'n, supra note 17, at 31.

20. Id. at 11 .

21. Id. at 13-14.

22. S.B. 1253, 85th Leg., Reg. Sess. (Tex. 2017), sent to the Governor May 24, 2017. 
enters the area of the place of detention in which the custodial interrogation will take place or receives” a Miranda warning, whichever occurs first. ${ }^{23}$

\section{Eyewitness Identification}

Current laws in Texas do not require departments to adopt a statewide policy regarding eyewitness lineups; instead, they allow each department to develop its own policy. ${ }^{24}$ At the federal level, the U.S. Department of Justice recently announced a department wide procedure for eyewitness identification that requires, among other things, agents who are not involved in the investigation and who do not know the identity of the suspect to be the ones who administer photo lineups. ${ }^{25}$ This is in line with the Commission's recommended Bill Blackwood Law Enforcement Management Institute of Texas Model Policy, ${ }^{26}$ which the Commission would make mandatory for all law enforcement agencies in Texas. $^{27}$

The ABA Report recommends that a court use a specific jury instruction whenever there has been a pretrial identification of a defendant, explaining "factors to be considered in gauging lineup accuracy," including a specific instruction on cross-racial identification. ${ }^{28}$ The ABA Report severely criticizes Texas's use of the "independent

23. Id. The Bill also includes a prohibition on the use of oral, sign language, or written statement without an electronic recording, with exceptions. Id.

24. See Tex. Code Crim. Proc. Ann. art. 38.20 (LEXIS through 2017 Sess.). House Bill 34, 85th Texas Legislative Session, is currently on its way to the Governor's desk and will make some changes in TEX. CODE CRIM. Proc. ANN. art. 38.20 (LEXIS through 2017 Sess.). If it becomes law, a witness must contemporaneously give their level of confidence as to the out-of-court identification. And, if that witness then makes an in-court identification the identification is admissible only if the evidence is accompanied by the prior details of the identification and their confidence level. See H.B. 34, 85th Leg., Reg. Sess. (Tex. 2017), http://www.capitol.state.tx.us/tlodocs/ 85R/billtext/pdf/HB00034S.pdf\#navpanes=0 [http://perma.cc/QPS2-5BZU].

25. Office of Pub. Affairs, Justice Department Announces Department-Wide Procedures for Eyewitness Identification, DEP'T OF JUSTICE (Jan. 6, 2017), https://www.justice.gov/opa/pr/justicedepartment-announces-department-wide-procedures-eyewitness-identification [http://perma.cc/C925-XTQ3].

26. Timothy Cole Exoneration Review Comm'n, supra note 17, at 53.

27. Id. at 20 .

28. Am. Bar Ass'n, supra note 2, at 49. The ABA Report provides a model jury instruction: In this case, the identifying witness is of a different race than the defendant. You may consider, if you think it is appropriate to do so, whether the fact that the defendant is of a different race tha[n] the witness has affected the accuracy of the witness' original perception or the accuracy of a later identification. You should consider that in ordinary human experience, some people may have greater difficulty in accurately identifying members of a different race than they do in identifying members of their own race.

Id. at 49 n.148. 
source rule," which permits identification in court by an eyewitness if the witness can claim some other independent source for the identification, even though the identification by the witness pre-trial was suggestive and unreliable. ${ }^{29}$ Yet, the Texas Code of Criminal Procedure and supporting case law continues to refuse to allow such an instruction. ${ }^{30}$

\section{Accountability}

Recommendation \#8, as to training of law enforcement, and Recommendation \#9, ensuring the public has "adequate opportunity" to report law enforcement misconduct in investigations, speak to the need for accountability. ${ }^{31}$ The ABA Report sets out several statutes that define training standards, licensing requirements, and to some degree, complaint and disciplinary procedures for the thousands of law enforcement agencies in Texas. ${ }^{32}$ However, the ABA Assessment Team, without explanation, concludes it "is unable to determine whether the State of Texas complies with Recommendations \#8 and \#9.”33 To its credit, Texas has a bureaucracy that would rival any, in its reach into the daily lives of Texans, despite its insistence on being a small government state.

The state agency that provides training of law enforcement personnel is The Texas Commission of Law Enforcement (TCOLE). ${ }^{34}$ TCOLE's mission "is to establish and enforce standards to ensure that the people of Texas are served by highly trained and ethical law enforcement, corrections, and telecommunications personnel." ${ }^{35}$ TCOLE provides a resource for those that want to lodge a complaint against law enforcement, but TCOLE plainly limits its authority to investigate law enforcement wrongdoing. ${ }^{36}$ TCOLE refers misconduct complaints on what it calls

\footnotetext{
29. Id. at 52 .

30. Tex. Code Crim. Proc. Ann. art. 36.14 (LEXIS through 2017 Sess.) (explaining that a jury charge should not express any opinion on weight of evidence). See Perry v. New Hampshire, 565 U.S. 228, 246 (2012) (noting many federal and state courts have adopted "eyewitness-specific jury instructions”). Texas courts have declined to allow jury instructions on mistaken identity as improper comments on the weight of the evidence. See Roberson v. State, 852 S.W.2d 508, 511 (Tex.Crim.App.1993) (holding that special instruction on mistaken identity would constitute improper comment on weight of evidence).

31. Am. Bar Ass'n, supra note 2, at 52.

32. Id. at $52-54 \mathrm{nn} \cdot 160-69$.

33. Id. at 54 .

34. See TeX. Occ. CodE ANN. § 1701 (Lexis through 2017 Sess.).

35. TCOLE Mission, TEX. COMM'N ON LAW ENF'T, https://www.tcole.texas.gov/content/tcole-mission [http://perma.cc/VS5Y-XTJS] (last visited Oct. 20, 2017).

36. Complaint Procedures, TEX. COMM'N ON LAW ENF'T, https://www.tcole.texas.gov/content/complaint-procedures\#Overview [http://perma.cc/AU5S-
} 
"non-jurisdictional” matters to the agency for which the law enforcement officer works. ${ }^{37}$ TCOLE may investigate "jurisdictional" matters, such as "violations of law or rules that relate to the licensing, training, certification, appointment of a license holder, or the conviction or placement on deferred adjudication of a license holder for a covered criminal offense." 38 So, to some degree, Texas does address Recommendations \#8 and \#9. The thousands of law enforcement agencies throughout the state in every county, city, and governmental entity must independently establish their own discipline procedures of which many follow the standards of the Commission on Accreditation for Law Enforcement Agencies. ${ }^{39}$ Why the ABA Report claims it is unable to determine if Texas complies with these recommendations probably has more to do with the mere size of the effort to verify whether the 1,913 law enforcement agencies in Texas satisfactorily meet the recommendations. ${ }^{40}$

\section{Informants}

The Timothy Cole Commission, as well as the ABA Report, were critical of the use of informants. A Bill is making its way to the Texas Governor which requires prosecutors to track "the use of testimony of a person to whom a defendant made a statement against the defendant's interest while the person was imprisoned or confined in the same correctional facility as the defendant" and any benefits offered or provided to a person in exchange for testimony. ${ }^{41}$ Texas has taken the recommendations of the Commission to heart.

E5MZ] (last visited Oct. 20, 2017)

37. Such non-jurisdictional matters would include "rudeness, unprofessional conduct, and improper investigations.” $I d$.

38. Id.

39. See Standards for Law Enforcement Agencies, The Standards Manual of the Law Enforcement Agency Accreditation Program 26-1 to -3, 5th ed., CALEA (2006), http://www.calea.org/ [http://perma.cc/C457-QTDH]; see W. Craig Hartley, Jr., Access the Standards for Law Enforcement Agencies Manual, 6th Edition, COMM'N FOR ACCREDITATION FOR LAW ENF'T AgENCIES (CALEA) (Apr. 2017), http://www.calea.org/content/access-law-enforcement-draftmanual [http://perma.cc/5H5M-THDZ].

40. According to the U.S. Bureau of Justice Statistics' 2008 Census of State and Local Law Enforcement Agencies, the state had 1,913 law enforcement agencies, the most of any state. These agencies employ 59,219 sworn police officers, about 244 for each 100,000 residents. Reaves, supra note 18 , at 15 .

41. H.B. 34, 85th Leg., Reg. Sess. (Tex. 2017). 


\section{Forensics}

The final recommendation of the Commission addresses improving forensic practices, as do the next two sections below, which address the recommendations of the ABA Report on the issues of the collection, preservation, testing of DNA and other evidence, crime laboratories, and medical examiner offices.

\section{B. Collection, Preservation, DNA Testing, and Other Evidence}

The collection and examination of biological evidence has become the gold standard in forensic science toward the ultimate goal of convicting only the guilty and exonerating the innocent. One can remember when crime scene investigations primarily involved the collection of hair and fiber evidence, fingerprints, serology — primarily to type the blood and draw rudimentary assumptions about its source-and photographic documentation of the scene. Forensic science techniques would be developed, labeled scientifically reliable, and given the court's approval for use in the prosecution of an accused to later be abandoned as "junk science" and their use discontinued. ${ }^{42}$ For the past 30 years, the use of DNA as the building block of life has narrowed criminology's view of investigation. ${ }^{43}$ Viewed by the public as "the voice of God," DNA has until recently seen a meteoric rise as THE unimpeachable forensic technique. ${ }^{44}$

Following the ABA's Resolution in 2000 encouraging the collection, preservation, and testing of biological evidence, the ABA Report acknowledged the widespread adoption of laws addressing the testing of biological evidence. ${ }^{45}$ Subsequently, in 2007, the ABA Criminal Justice Standards on DNA Evidence were compiled to reduce error and

42. Harry Edwards \& Jennifer Mnookin, A Wake-Up Call on the Junk Science Infesting our Courtrooms, THE WASH. POST (Sept. 20, 2016), https://www.washingtonpost.com/opinions/a-wakeup-call-on-the-junk-science-infesting-our-courtrooms/2016/09/19/85b6eb22-7e90-11e6-8d13d7c704ef9fd9_story.html?utm_term=.25f3c56a7d85 [http://perma.cc/6D9E-9535] (giving examples of junk science once admissible in court and now deemed unreliable such as bite mark analysis, firearms identification, footwear analysis, and microscopic hair comparisons).

43. Randy James, A Brief History of DNA Testing, TimE (June 19, 2009), http://content.time.com/time/nation/article/0,8599,1905706,00.html []http://perma.cc/3S7T-VFSC.

44. Darren K. Carlson, Americans Conclusive About DNA Evidence, GalluP (2005), http://www.gallup.com/poll/19915/americans-conclusive-about-dna-evidence.aspx

[http://perma.cc/2JJQ-ZMJS] ("More than 8 in 10 Americans (85\%) think DNA evidence is either completely (27\%) or very (58\%) reliable.”).

45. See Am. Bar Ass'n, Report No.115 (July 10-11, 2000), http://www.americanbar.org/content/dam/aba/migrated/moratorium/policy/2000s/2000_AM_115.au thcheckdam.pdf [http://perma.cc/KK49-TY33]. 
misconduct, as well as to further safeguard against convictions and executions of innocents. ${ }^{46}$

The ABA Report makes five recommendations which track fairly well the ABA's 2000 resolution referenced above and finds that Texas partially complies with each recommendation. ${ }^{47}$ These recommendations include (1) the State indefinitely preserving biological evidence taken in all felonies, (2) allowing equitable relief when the state fails to follow preservation requirements, (3) ensuring availability of DNA testing to any inmate looking to make a showing of innocence or lack of an aggravating factor-regardless of identity being an issue-(4) permitting postconviction testing and re-testing, and (5) updating written policies for the handling and preservation of biological evidence, with adequate funding. ${ }^{48}$

Contemporaneous with the issuance of the ABA Report, Texas amended its statute on the handling of biological, evidentiary material. The ABA Report is quick to acknowledge these efforts but still felt Texas was a bit short of the mark. To Texas's credit, Article 38.43 of the Code of Criminal Procedure was amended at that time to provide five paragraphs dealing with the testing of biological evidence in capital cases, what happens should biological evidence be lost or destroyed as a result of testing, and the use of alternative laboratories for testing. ${ }^{49}$ The ABA Report felt Texas should indefinitely preserve biological evidence in all violent crimes, ${ }^{50}$ ensure the availability of testing for convicted inmates who want to show a reasonable probability of their innocence of the crime or any aggravating conduct, ${ }^{51}$ develop procedures and policies as best practices for all law enforcement agencies, ${ }^{52}$ and have Texas provide the costs for long-term storage of biological evidence. ${ }^{53}$ None of these

\footnotetext{
46. See Am. Bar Ass'n, ABA Standards for Criminal Justice, DNA Evidence Standard 166.1(a)-(b), $115 \quad$ (2007), http://www.americanbar.org/content/dam/aba/publications/ criminal_justice_standards/dna_evidence.authcheckdam.pdf [http://perma.cc/3NXH-FHQ4].

47. See Am. Bar Ass'n, supra note 2, at 59-68.

48. See id.

49. S.B. 1292, 83rd Leg., Reg. Sess. (Tex. 2013) (amending by adding Subsections (i), (j), (k), (l), and (m) to Tex. Code CrIM. Proc. AnN. art. 38.43). This Article is entitled Evidence Containing Biological Material and addresses evidence in a criminal case which contains biological material. It defines what biological evidence means; makes the article applicable to all those that collect, store, preserve, analyze, or retrieve such evidence; sets limits on the preservation of such material; says how such evidence may be destroyed and stored; and sets specific requirements in death penalty cases for DNA and biological evidence testing and other matters specifically applicable to death cases. Id.

50. Am. Bar Ass'n, supra note 2, at 61.

51. Id. at 65.

52. Id. at 66 .

53. Id. at 67 .
} 
recommendations have been fully implemented since the ABA Report. Unfortunately, the statute that permits a convicted person to request from a court the right to have biological evidence forensically DNA tested was amended, effective September 1, 2015, to now require the person to show the evidence "has a reasonable likelihood of containing biological material." 54 This certainly narrows the inmate's options and provides the state another way to deny relief.

A word of caution must be uttered. Texas and the United States are building a database of DNA data. Texas's database includes all those: (1) indicted or who waive indictment for a felony prohibited or punishable under any of the following Penal Code sections, including aggravated kidnapping (inflicting bodily injury or abuse sexually), indecency with a child, sexual assault, aggravated sexual assault, prohibited sexual conduct, burglary of a habitation to commit a non-theft felony, compelling prostitution, sexual performance by a child, possession or promotion of child pornography, continual sexual abuse of young child or children, or continuous trafficking of persons; (2) arrested for any of the previously listed felonies after having been previously convicted of or placed on deferred adjudication for one of those offenses or for a second degree burglary of a habitation; or (3) convicted of homicide, kidnapping, unlawful restraint, smuggling of persons, trafficking of persons, sexual offenses and assaultive offenses punishable as a Class A misdemeanor or any higher category of offense (except for Class A misdemeanors of unlawful restraint, assault, or deadly conduct), or convicted of indecent exposure, enticing a child, promotion of prostitution, or the sale, distribution, or display of harmful material to minors. ${ }^{55}$ The database also includes: (1) an adult who is ordered by a magistrate or court to provide a DNA sample, including as part of an order granting community supervision to the individual or confined in a penal institution operated by or under contract with the Texas Department of Criminal Justice; (2) a juvenile adjudicated for conduct constituting a felony and confined in a facility operated by or under contract with the Texas Juvenile Justice Department, placed on probation for conduct constituting a felony that is listed in Article 42A.054(a), Texas Code of Criminal Procedure; or (3) for which a deadly weapon was used or exhibited during the commission of the conduct or during immediate flight from the commission of the conduct. ${ }^{56}$ This database must be enormous, with the addition of DNA

54. Tex. Code Crim. Proc. AnN. art. 64.01(LEXIS through 2017 Sess.). Amended by S.B. 487, 84th Leg., Reg. Sess. (Tex. 2015).

55. TeX. Gov’T CODE ANN. § 411.1471(a) (LEXIS through 2017 Sess.).

56. Tex. Code Crim. Proc. AnN. art. 42.12(3)(g) (LEXIS through 2017 Sess.) is now a part 
records from all state and federal jurisdictions. As 99\% of our DNA is commonly shared, and surely we are only beginning to understand the human genome, the collection of such personal information in a common source will only lead to abuse. It is only a matter of time until corporate interests want to invade the database to mine those who are statistically in good health, or those that share a common gene which is an indicator of a genetic illness, or to isolate those who can produce a favored eye, hair, or skin color, or have a genetic proclivity for higher intelligence. For those that consider this science fiction, there are those that are calling for a universal database of all our DNA. ${ }^{57}$ The potential for invasion of our privacy and abuse by those so inclined is chilling. I submit that the collection of DNA for identifying those that commit crimes in the future is a naïve purpose for what is a sinister device. Recidivism is easily mapped with current technology, and statistics and data are readily available. ${ }^{58}$

\section{Crime Labs and Medical Examiners}

The ABA Report is quite extensive in its analysis of forensic science service providers in Texas, including the service providers' accreditation and monitoring of their work. ${ }^{59}$ Further, Texas's two-tier system of Medical Examiner Offices in the larger counties and coroners in the smaller counties-usually performed by Justices of the Peace-create opposing challenges. ${ }^{60}$ The ABA Report recommends: "Crime laboratories and medical examiner offices should be accredited, examiners should be certified, and procedures should be standardized and published to ensure the validity, reliability, and timely analysis of forensic evidence.” ${ }^{61}$ The peer review characteristic of the system of accreditation

of Tex. Code Crim. Proc. AnN. art. 42A.053(a) (LEXIS through 2017 Sess.). The offenses remain the same: solicitation of capital murder, murder, capital murder, aggravated kidnapping, trafficking of persons, indecency with a child, sexual assault, aggravated sexual assault, injury to a child, elderly individual, or disabled individual (with exceptions), aggravated robbery, burglary (with limitations), compelling prostitution, sexual performance by a child, or Health and Safety Code violations using a child in the commission of an offense, a drug offense in a drug free zone (with limitations). It was much simpler when we called them $3 g$ offenses. I wonder whether even though we have changed statute numbers if practitioners will still call these offenses 3g's?

57. Arnold Loewy, A Proposal for the Universal Collection of DNA, 48 TEX. TECH L. REV. 262 (2015)

58. E.g., Patrick A. Langan \& David J. Levin, Recidivism of Prisoners Released in 1994, DEP’T OF Justice, 1 (June 2002); No. 1 Recent State Reforms II: The Impact of New Fiscal and Political Realities, Fed. Sentencing Reporter, 15 Univ. of Cal. Press 3 (Oct. 2002).

59. Am. Bar Ass'n, supra note 2, at 71-76.

60. See TeX. Code Crim. Proc. AnN. art. 49.25 (LEXIS through 2017 Sess.).

61. Am. Bar Ass'n, supra note 2, at 81. 
was further criticized for lack of impartiality. ${ }^{62}$ The anecdotal examples of the failures of laboratories in Texas highlighted the need for better accreditation programs. ${ }^{63}$ The second recommendation within the ABA Report includes providing adequate funding for both crime laboratories and medical examiner offices to ensure "accurate and reliable results" by hiring a "sufficient number of competent forensic scientists and staff" to provide analysis in a timely manner, minimizing unreasonable delay. ${ }^{64}$

One important change in Texas law has occurred since the ABA Report was published, which addresses several of these concerns. After problems in the Houston Police Department crime lab in 2005, the Texas Legislature created the Texas Forensic Science Commission (FSC). ${ }^{65}$ The initial mission of the FSC was to "strengthen the use of forensic science in criminal investigations and courts by developing a process for reporting professional negligence or misconduct, investigating allegations of professional negligence or misconduct, promoting the development of professional standards and training, and recommending legislative improvements." ${ }^{\prime 66}$ Although the Commission came perilously close to being just another ineffective governmental political body, ${ }^{67}$ in 2013 and 2015, several substantive changes were made which directly affected the two recommendations of the ABA Report. ${ }^{68}$

The original 2005 statute creating the FSC ${ }^{69}$ was amended in 2013, adding additional investigative and reporting responsibilities to the FSC, further expanding the FSC's duty to implement a system whereby crime laboratories were required to "report professional negligence or professional misconduct." 70 Although there were some specific limitations within the 2013 amendment-such as being prevented from making a finding of negligence or misconduct ${ }^{71}$ and differentiations

\footnotetext{
62. Id. at 83 .

63. Id. at 91. See id. at 83-91 for examples of failures in Houston.

64. Id. at 91 .

65. Tex. Code Crim. Proc. Ann. art. 38.01 (LEXIS through 2017 Sess.).

66. Tex. Forensic Sci. Comm'n, Policies and Procedures, 2 (2010) http://www.fsc.texas.gov/sites/default/files/policies/D_PoliciesandProcedures012910.pdf [http://perma.cc/8FVU-N7GM].

67. Michael Hall, False Impressions, TEX. Monthly (Jan. 2016), http://www.texasmonthly.com/articles/false-impressions/ [http://perma.cc/NT7S-5PDF].

68. See TeX. Code Crim. Proc. ANN. art. 38.01 (LEXIS through 2017 Sess.).

69. Id., original statute added by H.B. 1068, 79th Leg., Reg. Sess. (Tex. 2005).

70. See S.B. 1238, 83rd Leg., Reg. Sess. (Tex. 2013), amending Tex. Code Crim. Pro. ANn. art. $38.01 \S 4$ (LEXIS through 2017 Sess.), adding the word "professional" before the word conduct and striking the agencies required to report from "accredited laboratories, facilities, or entities" to just "crime laboratory."

71. Tex. Code Crim. Proc. AnN. art. $38.01 \S 4$ (f) (LEXIS through 2017 Sess.).
} 
between accredited and unaccredited laboratories and forensic fields ${ }^{72}$ reports of the FSC were required to now include observations about the integrity and reliability of a forensic analysis, preferred best practices, recommendations presumably to remedy the problem, and who should be responsible for the cost of the follow-up to test compliance. ${ }^{73}$

Prior to the 2015 changes, the Director of the Department of Public Safety established an accreditation process and exemptions for crime laboratories and other entities. ${ }^{74}$ One of the most important parts of the 2015 amendments was the reassignment of oversight in the accreditation of crime laboratories (and other entities) and forensic analysis from the Director of the Department of Public Safety to the FSC. ${ }^{75}$ Consequently, the FSC was given the charge to "establish procedures, policies, and practices to improve the quality of forensic analyses" in Texas. ${ }^{76}$ The FSC may also establish a licensing program for forensic disciplines if it chooses. ${ }^{77}$ Additionally, those that perform forensic analysis-the forensic analysts-must now be licensed by January 1, 2019. ${ }^{78}$ The new amendments now define a forensic analyst as one:

who on behalf of a crime laboratory accredited under this article (Art. 38.01 C.C.P.) technically reviews or performs a forensic analysis or draws conclusions from or interprets a forensic analysis for a court or crime laboratory. The term does not include a medical examiner or other forensic pathologist who is a licensed physician. ${ }^{79}$

Although the process will never be perfect, Texas has complied with the spirit of the recommendations in the ABA Report by implementing these changes. Crime laboratories and those that work within them will be accredited by a state agency, which ostensibly is no longer associated with law enforcement. The FSC consists of nine members who serve a two-

72. Compare id. $\S 4(\mathrm{~b}-1)$ (mandating that reporting of investigation not mandatory), with id. $\S \S 4(\mathrm{~b})$ and 4(b-2) (mandating that reporting of investigation is mandatory when looking at accredited crime laboratories and forensic analysis who both by definition must be accredited by the State).

73. See S.B. 1238, 83rd Leg., Reg. Sess. (Tex. 2013), amending Tex. Code Crim. Pro. Ann. art. $38.01 \S 4$ (LEXIS through 2017 Sess.).

74. TeX. Gov’T CODE ANN. § 411.0205 (LEXIS through 2017 Sess.) (re-designated as TeX. CODE CRIM. PRo. ANN. art. 38.01 (LEXIS through 2017 Sess.)).

75. See S.B. 1287, 84th Leg., Reg. Sess. (Tex. 2015) (amending TEx. Code. Crim. Pro. AnN. art. $38.01 \S \S 2$ 2, 2(1), 3(a), 4, 4(b), 4(b-1) (LEXIS through 2017 Sess.)) and SB 1743, 84th Leg., Reg. Sess. (Tex. 2015) (amending TeX. Code Crim. Pro. ANN. art. $38.01 \S 8$ (LEXIS through 2017 Sess.)). TeX. Code Crim. Pro. ANN. art. $38.01 \S 4$-a(b) (LEXIS through 2017 Sess.), takes effect Jan. 1, 2019.

76. Tex. Code Crim. Proc. AnN. art. $38.01 \S 4$ 4-d (b-1)(3) (LEXIS through 2017 Sess.).

77. Id. § 4-a (2)(c).

78. Id. § 4-a (b).

79. Id. § 4-a (a)(2). 
year term. ${ }^{80}$ The commission members serve at the pleasure of the Governor ${ }^{81}$ without pay. ${ }^{82}$ By statute, the commission consists of one criminal defense lawyer, one district attorney, and seven doctors, scientists, professors, and forensic science professionals. ${ }^{83}$ As to funding, the FSC has a budget of $\$ 500,000$ annually ${ }^{84}$ and employs three full-time employees. ${ }^{85}$ Texas has gone the extra mile to address the issues raised by the ABA Report.

One problem that persists is that medical examiner offices are still not included in the oversight of the FSC, as medical examiner offices are staffed by medical doctors and are subject to their own accreditation and inspection requirements. ${ }^{86}$ Also, Texas law permits a patchwork of medical examiners and coroners - in some locales, Justices of the Peacewhich creates problems in the more serious cases. ${ }^{87}$ The laws dealing with these issues should be modernized and brought within the watchful eye of the FSC.

Overall, considering the pervasive growth of junk science during the last few decades, the issues seen in crime laboratories throughout Texas and the resulting injury to the fair administration of justice these problems have created, the FSC and the proper funding and support of the commission by the state is a giant leap forward.

\section{Prosecution}

The fifth chapter of the ABA Report is a section on prosecution. The ABA Report sets out six recommendations as to prosecution. Twentythree surveys were sent to District Attorney Offices, and only two were

80. Id. § $3(\mathrm{a}-\mathrm{b})$

81. Id.

82. Id. § 5 .

83. Id. $\S 3$ (a).

84. See Tex. Forensic Sci. Comm'n, Fifth Annual Report 9 (Dec. 2015- Nov. 2016), http://www.fsc.texas.gov/sites/default/files/documents/files/2016\%20Annual\%20Report\%20.pdf [http://perma.cc/V3VK-URUV].

85. See Tex. Forensic Sci. Comm'n Staff, Commission Staff, http://www.fsc.texas.gov/staff [http://perma.cc/B3X2-57D3] (last visited Oct. 20, 2017).

86. Tex. Code Crim. Proc. ANN. art. 49.25 (LEXIS through 2017 Sess.). Medical examiners should have training and experience in pathology, toxicology, histology, and other medico-legal sciences. Id. § 2.

87. L. Maximilian Buja, Historical Vignette Texas Tragedies and the Evolution of the Medical Examiner System in Texas, TEX. SOC'Y OF PATHOLOGISTS (2009) http://www.texpath.org/assets/legacy/publications/tsphistoricalvignette4-1-09.pdf [http://perma.cc/8J6K-H5KL]. From my experience, medical examiners in Texas are medical doctors, and coroners are primarily justices of the peace without formal medical training. 
returned. ${ }^{88}$ Perhaps more than anything else, this lack of participation in the ABA's efforts (1) to make the capital punishment system in Texas fair in the selection of those chosen to face the death penalty, (2) while reducing the risk of executing the innocent, and (3) preserving the confidence of the public in the administration of criminal justice, highlights a primary problem with the Texas system. ${ }^{89}$ When politicians (prosecutors and to a lesser degree judges) rely upon the death penalty for their political lives, it is no wonder the system is unfair, and the risk of executing the innocent continues. This personality driven exercise of power given to prosecutors in selecting and prosecuting those subject to the death penalty is less about the crime and more about the "personality and predilections of the local prosecutors entrusted with the power to seek the ultimate punishment .... . It better reflects the lack of meaningful controls on prosecutorial discretion and a lack of consequences for their illegal or unethical behavior." 90

\section{Recommendation \#1: Prosecutorial Discretion}

The six recommendations in the ABA Report for the improvement of prosecution in Texas capital cases are very reasonable and their implementation would improve the Texas system. For example, Recommendation \#1 says prosecutor offices should have written policies governing the exercise of discretion. I have previously written on over 140 crimes in Texas that could be prosecuted as capital crimes. ${ }^{91}$ I have argued that the Texas statute is now totally unconstitutional, "that it has 'unevolved' once again into a vehicle which drove previous capital statutes to be stricken as capricious, arbitrary, racist, and violative of the Eighth Amendment."92 A statute mandating a death penalty review panel within each District Attorney's office in Texas, similar to that described as policy in Dallas, would most likely meet the ABA's recommendation and allow a proper consideration of the complicated issues involved in the decision that should occur prior to the election to seek a death sentence. ${ }^{93}$

\footnotetext{
88. Am. Bar Ass'n, supra note 2, at xxvii.

89. Id. at iii. In the first paragraph of the ABA Report, under the section entitled Highlights and Key Recommendations of the Texas Report, the ABA Report quotes these reasons necessitating the ABA's Texas Capital Punishment Assessment Report.

90. America's Top Five Deadliest Prosecutors: How Overzealous Personalities Drive the Death Penalty, FAIR PUnISHMENT PROJECT, 25 (2016), http://fairpunishment.org/wpcontent/uploads/2016/06/FPP-Top5Report_FINAL.pdf [http://perma.cc/6YDE-TAV8].

91. Patrick S. Metze, Death and Texas: The Unevolved Model of Decency, 90 NeB. L. REV. 240, 330 (2011).

92. Id. at 242.

93. Am. Bar Ass'n, supra note 2, at 105.
} 
Removing the discretion from the elected District Attorney would give the District Attorney a layer of cover for the decision of whether to subject someone to a potential death sentence.

\section{Recommendation \#2: Evidentiary Concerns}

The ABA Report encourages District Attorney's offices to establish procedures for looking at cases that have eyewitness identification, a confession, jailhouse snitch, or informant testimony. ${ }^{94}$ This is about wrongful convictions. As law enforcement should establish written policies, ${ }^{95}$ so should prosecutors.

To Texas's credit, the creation of the Timothy Cole Exoneration Review Commission ${ }^{96}$ to investigate wrongful convictions and the increasing use of Conviction Integrity Units ${ }^{97}$ within District Attorney's offices are signs that Texas once again is leading the way on these important issues.

In December 2016, a 59-page report was issued by the Timothy Cole Exoneration Review Commission making a dozen recommendations to the legislature for laws which could improve Texas's criminal justice system. ${ }^{98}$ This work came after the creation of the Timothy Cole Advisory Panel on Wrongful Convictions (TCAP) report of 2010. ${ }^{99}$ Most of the recommendations of the TCAP have now been implemented. ${ }^{100}$ If the legislature and the Court of Criminal Appeals would increase its mandatory training for prosecutors in these areas perhaps fewer problems will arise. A combination of legislation and court oversight has shown to effect meaningful change. Such a dual approach has changed the face of discovery in Texas as illustrated in the response to Recommendation \#3.

94. Id. at 108.

95. See James D. Brown, Protection Through Written Policies, CALEA Update MagazinE, Issue 105, CALEA, http://www.calea.org/calea-update-magazine/issue-105/protection-throughwritten-policies [http://perma.cc/5LX8-2XSG]. 16.

96. TeX. Code Crim. Proc. AnN. art. 43.27 (LEXIS through 2017 Sess.); Rafique, supra note

97. Noah Fromson, Conviction Integrity Units Expand Beyond Lone Star State Roots, THE TEX. TRIBUNE (Mar. 12, 2016), https://www.texastribune.org/2016/03/12/conviction-integrity-unitsexpand-beyond-texas-roo/ [http://perma.cc/N6VV-KD2V].

98. See Timothy Cole Exoneration Review Comm'n, supra note 17, at 1 . The 12 recommendations were in the areas of electronic recording of interrogations, false accusation/informant regulation, faulty eyewitness identification, and forensic science practices. Virtually all these areas are addressed by the ABA Report and discussed herein.

99. Timothy Cole Advisory Panel on Wrongful Convictions, Report to the Texas Task Force on Indigent Defense, (2010), http://www.tidc.texas.gov/media/25663/FINALTCAPreport.pdf [http://perma.cc/5YEN-VYJN].

100. Timothy Cole Exoneration Review Comm'n, supra note 17, at 9-10. 


\section{Recommendation \#3: Discovery}

The discovery process in Texas has seen dramatic changes. Within the year of the ABA Report came the amendment of article 39.14 of the Texas Code of Criminal Procedure and the famed implementation of the Michael Morton Act. ${ }^{101}$ Not to take effect until January 1, 2014, after the ABA Report, this statute was a sea change in the way Texas saw the responsibility of the prosecution in pretrial discovery. With this change came a renewed emphasis to follow the teachings of Brady $v$. Maryland. ${ }^{102}$ The Texas Legislature created $\S 41.111$ of the Texas Government Code making training related to a prosecutor's duty to disclose exculpatory and mitigating evidence mandatory for all those that represent the state in the prosecution of felony and misdemeanor criminal offenses. ${ }^{103}$ Additionally, the Supreme Court of Texas, through its State Bar Rules, reemphasized the prosecutor's ethical duty to "make timely disclosure to the defense of all evidence or information known to the prosecutor that tends to negate the guilt of the accused or mitigates the offense, and, in connection with sentencing, disclose to the defense and to the tribunal all unprivileged mitigating information known to the prosecutor." 104 The combination of legislation, mandatory education and reporting requirements, oversight by the courts, and enforcement of the Texas Disciplinary Rules of Professional Conduct through the State Bar grievance process is an effective way to force prosecutors to implement any of the policies in the ABA Report's recommendations.

\section{Recommendations \#4, \#5, and \#6}

The final three recommendations have seen no significant change since the ABA Report. Recommendation \#4 emphasizes that prosecutors should continue to instruct their agencies, laboratories, and experts of the obligation to provide exculpatory and mitigating evidence. ${ }^{105}$ There is nothing new here. Recommendation \#6 speaks to providing funds for

101. S.B. 1611, 83rd Leg., Reg. Sess. (Tex. 2013).

102. Brady v. Maryland, 373 U.S. 83 (1963) (granting petitioner a new trial only on the issue of punishment on due process grounds after the state suppressed evidence that another person had admitted to the murder, but ruling that the suppressed statement was inadmissible for the issue of guilt).

103. TEX. Gov’T CODE ANN. § 41.111 (LEXIS through 2017 Sess.) (created by H.B. 1847, 83rd Leg., Reg. Sess. (Tex. 2013)). This statute created a one hour training mandatory for all new prosecutors within 180 days of first employment and set a one year requirement on the education of current prosecutors, with reporting requirements. Id.

104. Tex. R. Prof. Conduct 3.09(d) (LEXIS through 2017 Sess.).

105. Am. Bar Ass'n, supra note 2, at 122-23. 
training of the prosecution team. ${ }^{106}$ There are ample opportunities in Texas for training. ${ }^{107}$ Finally, Recommendation \#5 suggests the implementation of policies and procedures to appropriately discipline prosecutors for misconduct. ${ }^{108}$ Below are three anecdotal incidents which give hope in this regard.

First is the prosecution of former prosecutor Ken Anderson, the District Attorney who prosecuted Michael Morton and failed to disclose favorable information to the defense. ${ }^{109}$ This was the first time the attorneys involved had heard of a prosecutor being prosecuted for criminal offenses for this type of misconduct. ${ }^{110}$ Even though he ultimately was only found guilty of criminal contempt and sentenced to ten days in jailplus the loss of his law license-this case is a milestone toward the day prosecutors will put justice before their careers. ${ }^{111}$

Next, in February 2016, former Texas prosecutor Charles Sebesta was disbarred by the State Bar of Texas for sending Anthony Graveswho was later found innocent - to death row by using tainted testimony and making false statements. ${ }^{112}$

Finally, the State Bar of Texas recently attempted to disbar a former prosecutor, John Jackson, who famously sent Cameron Todd Willingham to death row in Texas in $1992 .{ }^{113}$ Willingham was executed for the death of his three daughters in 2004 and is believed by many to be innocent of

106. Id. at 131

107. The website for the Texas County and District Attorney's Association shows 11 training sessions throughout the year, see 2017 Seminar Schedule, TEX. CTY. AND DisT. ATTORNEY’s Ass'N, https://www.tdcaa.com/sites/default/files/seminar/2017_Seminar_Schedule.pdf [http://perma.cc/36AE-96U2]. This does not include all the opportunities available through the State Bar of Texas, see State Bar of Texas, TEXAS BAR CLE, http://www.texasbarcle.com/CLE/Home.asp [http://perma.cc/LVR8-DACH] (last visited Oct. 20, 2017).

108. Am. Bar Ass'n, supra note 2, at 124.

109. Maurice Chammah, Anderson Appeals, Citing Statute of Limitations, THE TEX. TRIBUNE (Apr. 23, 2013), https://www.texastribune.org/2013/04/23/judge-rules-anderson-court-inquiry/ [http://perma.cc/X6F5-2H87].

110. Molly Hennessy-Fiske, Ex-prosecutor Punished for Withholding Evidence in Murder Case, L.A. TIMES (Nov. 8, 2013), http://www.latimes.com/nation/la-na-texas-judge-20131109story.html [http://perma.cc/HYD3-JKEC].

111. Chuck Lindell, Ken Anderson to Serve 10 Days in Jail, AUSTIN-AMERICAN STATESMAN (Nov. 8, 2013), http://www.statesman.com/news/ken-anderson-serve-daysjail/F1jLxZBsk9Hry2vTpRt27N/ [http://perma.cc/9QX6-U9US].

112. Jon Herskovitz, Former Texas Prosecutor Disbarred for Sending Innocent Man to Death Row, REUTERS (Feb. 9, 2016), http://www.reuters.com/article/us-texas-prosecutoridUSKCN0VH25G [http://perma.cc/D3XK-BK6P].

113. Maurice Possley, Fresh Doubts Over a Texas Execution, THE WAsh. Post (Aug. 3, 2014), http://www.washingtonpost.com/sf/national/2014/08/03/fresh-doubts-over-a-texasexecution/?utm_term=.197a55dbca3f [http://perma.cc/S69A-BK77]. 
the crime. ${ }^{114}$ A complaint against Jackson was filed asking the State Bar of Texas to revoke his law license, alleging Jackson made false statements, concealed evidence favorable to Willingham's defense, and obstructed justice. ${ }^{115}$ A jury found in favor of Jackson. ${ }^{116}$

\section{Approaching Prosecutorial Misconduct}

Just as the State of Texas has addressed the specific issue of withholding exculpating or mitigating evidence from a defendant, the State should use a four-pronged approach for prosecutorial misconduct. First, legislation should be passed making the type of intentional prosecutorial misconduct described above actionable. In the most serious cases it should be criminal. Statutes of limitations and prosecutorial immunity statutes should allow prosecution for these wrong doings many years after the commission of the crimes and without the shield of immunity. Next, there must be mandatory education for prosecutors on these issues as the State has required as to Brady issues. The legislature must make it mandatory that those that prosecute are required to report violations. Prosecution for misprision should be allowed for all that knew of the violation, but did not speak up. ${ }^{117}$ The responsibility to report should be upon all officers of the court, not just prosecutors, but defense lawyers and judges, as well. Finally, the State Bar of Texas should continue its vigorous prosecution for violations of the Rules of Professional Conduct. I am encouraged that the former prosecutor in the Willingham case had his day in court and had to justify his actions. For a profession built upon the adversarial process, we should be proud that the State Bar and its membership are standing up and making prosecutors accountable for their behavior. It is not a matter of winning or losing these grievance complaints. The mere fact the actions were filed and vigorously prosecuted in all three of the above examples gives hope. ${ }^{118}$

\footnotetext{
114. Id.

115. Id.

116. Maurice Possley, Former Prosecutor Cleared of Misconduct in Texas Death Penalty Case,
} THE WASH. POST (May 11, 2017), https://www.washingtonpost.com/national/former-prosecutorcleared-of-misconduct-in-texas-death-penalty-case/2017/05/11/f5c3d24c-3662-11e7-b373418f6849a004_story.html?utm_term=.d0f90d436985 [http://perma.cc/R7R5-XHVA].

117. See infra note 190 (showing the duty to report being placed on all officers of the court).

118. See Radley Balko, The Untouchables: America's Misbehaving Prosecutors, and the System That Protects Them, THE Huffington POST (Aug. 1, 2013, updated Aug. 5, 2013), http://www.huffingtonpost.com/2013/08/01/prosecutorial-misconduct-new-orleanslouisiana_n_3529891.html [http://perma.cc/D7CK-PAWG]. 


\section{E. Defense}

Chapter Six of the ABA Report is on defense services. The five recommendations in this chapter address compliance with the ABA Guidelines on the Appointment and Performance of Defense Counsel in Death Penalty Cases. ${ }^{119}$ The ABA Report recommends the State follow its own State Bar guidelines, which were based upon the ABA Guidelines. ${ }^{120}$ From experience, the defense bar in Texas, and to an increasingly significant degree the judiciary in Texas, both take the guidelines seriously and attempt to comply. There are a few exceptions, but the State of Texas has provided the defense bar the basic tools for a successful defense, including the creation of several state offices, which deal specifically with these issues. ${ }^{121}$

One criticism of the current system is the tendency of the judiciary to not appoint an adequate trial team, as outlined in Guidelines 1.1 and 4.1 of the ABA Guidelines, until the prosecutor determines if she will waive death. ${ }^{122}$ This allows the prosecution to game the system in several ways. First, by delaying the decision on death, precious time is lost for the preparation of a proper defense. Mitigation evidence must be obtained as soon as possible, and these delays often cause the loss of records and

119. Am. Bar Ass'n, supra note 2, at 147-89; see ABA Guidelines on the Appointment and Performance of Defense Counsel in Death Penalty Cases, 31 Hofstra L. REV. 913 (2003) https://www.americanbar.org/content/dam/aba/migrated/2011_build/death_penalty_representation/2 003guidelines.authcheckdam.pdf [http://perma.cc/8KYA-M5FE].

120. See generally State Bar of Texas, Guidelines and Standards for Texas Capital Counsel (2006),

https://www.texasbar.com/AM/Template.cfm?Section=Consider_a_State_Bar_Committee\&Templa te $=/ C M / C o n t e n t D i s p l a y . c f m \& C o n t e n t I D=28741 \quad[h t t p: / / p e r m a . c c / N 7 N U-P E W Z] \quad$ (making recommendations in line with the ABA report); see also generally Supplementary Guidelines and Standards for the Mitigation Function of Defense Teams in Texas Death Penalty Cases, 78 TEX. BAR JOURNAL 460 (2015), https://www.texasbar.com/AM/ Template.cfm?Section=Past_Issues\&Template=/CM/ContentDisplay.cfm\&ContentID=30513 [http://perma.cc/XW2E-3G4E].

121. To assist the defense bar, the creation of the Regional Public Defender for Capital Cases to serve rural Texas, the Office of Capital Writs, and the Texas Indigent Defense Commission are a giant step forward. These agencies, and others, provide quality assistance and service previously denied in many portions of the state. Continuing its support for the reform of the criminal justice system in Texas are numerous Bills introduced in the 85th Regular Session of the Texas Legislature currently underway as this Article is written. One of the most important reforms is the Bill creating the Office of the Capital Appellate Defender. The Bill was voted out of committee in March and is waiting a vote in the House. The progress of this Bill can be followed at Texas Legislature, http://www.capitol.state.tx.us/BillLookup/History.aspx?LegSess=85R\&Bill=HB1676 [http://perma.cc/A8G3-GEQR] (last visited Oct. 21, 2017).

122. Eric Freedman, 'The Guiding Hand of Counsel': ABA Guidelines for the Appointment and Performance of Defense Counsel in Death Penalty Cases, 31 Hofstra L. Rev. 903, 919-52 (2003) (explaining the history of Guideline 1.1). 
memories as witnesses and their records disappear, are destroyed, or become otherwise unavailable. Additionally, many times what can be filed as a capital case is initially filed as a less serious murder not immediately triggering the appointment of a trial team required by the Guidelines. ${ }^{123}$ Further gamesmanship includes the interviewing of potential mitigation witnesses by the grand jury for the purpose of unfairly narrowing one's testimony and attempting to foreclose mitigation development. If a case falls within one of the 146 or more different ways to commit capital murder in Texas, the ABA Report recommends following the Guidelines as to appointment of a trial team immediately upon arrest or detention. ${ }^{124}$

The ABA Report criticizes the lack of consistent statewide rules on qualifications of counsel in death cases, the elected judges being overly involved in the appointment, compensation and monitoring schemes in most jurisdictions, and the lack of a consistent statewide system for funding of the defense. ${ }^{125}$ In a legislative session such as the one presently underway in Texas - where the Legislature is turning itself inside out to cut spending - and in a State as diverse as Texas with so many very poor, sparsely populated counties and some of the most extremely wealthy, large counties in the country, finding a solution that will fit the entire state is impossible. ${ }^{126}$ One suggestion is that a state public defender office should be created with offices in all the counties of Texas, employing thousands of lawyers and support staff equal to the size and resources provided to law enforcement and prosecution. This will never happen. Texas budgets almost $\$ 12$ billion dollars for public safety and criminal justice per year. ${ }^{127}$ Texas will never understand that the fair funding of the adversarial system is as integral to public safety and freedom as the

123. Anecdotally, in Lubbock, this technique results in the attorney appointed on the less serious charge of murder-although still a very serious first degree felony-doing preparation which significantly affects the indigent defense budget for the county. When the more serious capital murder is eventually filed, the Regional Public Defender for Capital Cases assumes the case, and the work of the first attorney is lost. The resulting cost negatively affects funds available for other indigent defendants. Some believe the District Attorney's Office does this intentionally.

124. Am. Bar Ass'n, supra note 2, at 147. See also Metze, supra note 91, at Appendix A (giving a description of 146 different ways capital murder can be charged in Texas, under the statute in effect in 2011).

125. Am. Bar Ass'n, supra note 2, at 141-45.

126. See Ross Ramsey, Straus to Patrick: Pass Two Bills, Avoid a Special Session of the Texas Legislature, THE TEX. TRIBUNE (May 16, 2017), https://www.texastribune.org/2017/05/16/strauspatrick-pass-two-bills-avoid-special-session-texas-legislature/ [http://perma.cc/N8E8-NPGH]. Within a few days of the close of the legislative session, the Texas Legislature has not passed a budget, which is required by the Texas Constitution.

127. See Texas Governor Greg Abbott, Texas Proposed Budget (2017), http://gov.texas.gov/budget [http://perma.cc/KSC2-Q59N] (last visited Oct. 20, 2017). 
funding of law enforcement, prosecution, and corrections. Meeting the recommendations of the ABA Report as to defense issues will continue to be a struggle primarily fought by the lawyers that represent those accused of capital murder. Although the state has made great strides highlighted by the many successes outlined in this paper, the defense bar will have to continue its fight, case by case, court by court, county by county, to get the compensation and resources necessary for a proper capital defense.

\section{F. The Direct Appeal Process and Proportionality Review}

The chapter on appeal process makes one recommendation that the Court of Criminal Appeals, on a direct appeal of a death sentence, should “engage in meaningful proportionality review...."128 During the analysis portion of the chapter, the ABA Report makes the point that because of the size and decentralized design of the Texas system, that less than half of the counties in Texas have given a death sentence in the modern era with $76 \%$ of those sentences coming from twenty counties, ${ }^{129}$ and four counties accounting for half of the sentences of death imposed. ${ }^{130}$ Texas does not perform a proportionality review in death cases, unlike most of the states that have the death penalty. ${ }^{131}$ There has been no change in Texas law since the ABA Report. Neither the statutes nor the opinions of the Texas Court of Criminal Appeals indicate a change is coming. The last time the Court of Criminal Appeals did more than summarily dismiss a claim for proportionality was in 2006, upholding the long-standing rule in Texas that a proportionality review in a death case is not constitutionally required. ${ }^{132}$ Although no legislation was proposed in the last legislative session, the remedy here is for the legislature to make such review a part of the direct appeal process. ${ }^{133}$

128. Am. Bar Ass'n, supra note 2, at 203.

129. Id.

130. Id. at 207.

131. Id. at 204.

132. Renteria v. State, 206 S.W.3d 689, 707 (Tex.Ct.App. 2006) (citing King v. State, 953 S.W.2d 266, 273 (Tex.Ct.App. 1997)). See Pulley v. Harris, 465 U.S. 37, 50-51 (1984) (holding no 8th Amendment requirement); see McFarland v. State, 928 S.W.2d 482, 497 (Tex.Crim.App. 1996) and Hughes v. State, 897 S.W.2d 285, 294 (Tex.Crim.App. 1994) (holding that a proportionality review under the Texas Constitution would not benefit petitioner because the evidence pointed to as mitigating did not outweigh the State's evidence).

133. See Search Results, Texas Legislature Online, http://www.capitol.state.tx.us/Home.aspx [http://perma.cc/S8SW-PCQ9] (last visited Oct. 20, 2017) (select “85(1) - 2017”; select "Word/Phrase;" then search "proportionality”). 


\section{G. State Habeas Corpus Proceedings}

The ABA Report makes 12 recommendations in the Texas postconviction habeas procedure. ${ }^{134}$ The Texas statute governing these procedures has not been changed since the issuance of the ABA Report, except some minor changes. ${ }^{135}$ In 2015, the Texas Legislature changed the name of the Office of Capital Writs making it the Office of Capital and Forensic Writs. ${ }^{136}$ The only change in the habeas statute was the addition of the words "and forensic" between the words "capital" and "writs" changing the focus of the state writ office. ${ }^{137}$ This was obviously done to correspond with the changes in the duties of the Forensic Science Commission and other emphasis on forensic science seen in recent years. ${ }^{138}$ The ABA Report “applauds” Texas for establishing the Office of Capital (and Forensic) Writs as the agency that represents death row inmates in habeas proceedings. ${ }^{139}$

During the 2017 Session currently underway, only one Bill that affects the habeas statute in capital cases has been passed by both the House and Senate. ${ }^{140}$ This Bill would allow previously tested biological evidence to be retested if the testing used at trial was done by the state at a laboratory that used faulty testing practices causing the lab to cease doing DNA testing after an audit by the Texas Forensic Science Commission. ${ }^{141}$ No other Bills trying to amend the state capital habeas statute made it out of committee. ${ }^{142}$

Since the ABA Report was issued, none of its recommendations as to habeas have seen implementation. The fairness of post-conviction relief in Texas is non-existent. The hope is the new writ office providing specific statewide representation in this area can bring about changes. The

134. Am. Bar Ass'n, supra note 2, at 215-51. In the interest of space, the 12 recommendations will not be repeated here.

135. Tex. Code Crim. Proc. ANN. art. 11.071 (LEXIS through 2017 Sess.); see S.B. 1743, 84th Leg., Reg. Sess. § 1-5 (Tex. 2015) (listing changes to 11.071).

136. See S.B. 1743, supra note 129 (amending TEX. Gov’T CODE ANN. §§ 78.051-78.056 (LEXIS through 2017 Sess.)).

137. Id.

138. E.g., TeX. Code Crim. Proc. ANN. art. 38.01 (LEXIS through 2017 Sess.).

139. Am. Bar Ass'n, supra note 2, at 235.

140. See H.B. 3872, 85th Leg., Reg. Sess. (Tex. 2017).

141. Id.

142. Search Results, Texas Legislature Online Search, http://www.capitol.state.tx.us/Search/ TextSearchResults.aspx?CP=1\&LegSess=85R \&House=true $\&$ Senate=true $\&$ TypeB=true $\&$ Type $=$ fa lse\&TypeJR=true $\&$ TypeCR=false $\&$ VerInt=true $\&$ VerHCR=true $\&$ VerEng=true $\&$ VerSCR=true $\&$ Ve rEnr=true\&DocTypeB=true\&DocTypeFN=true\&DocTypeBA=true\&DocTypeAM=true \&Srch=cust om \&Custom=11.071\&All=\&Any $=\& E x a c t=\& E x c l u d e=[$ http://perma.cc/33EK-YQV6] (last visited Oct. 21, 2017) (search "11.071" in the "With all of the words" field). 
restrictiveness of the Texas habeas statute makes relief almost impossible. As to qualification and compensation of habeas counsel, in time, the Office of Capital and Forensic Writs will professionalize Texas's state habeas procedure. All other substantive changes recommended by the ABA Report must come through amendment of the habeas statute or court edict after the constitutionality of the Texas procedure is successfully challenged.

\section{H. Clemency}

The chapter of the ABA Report on clemency goes through a thoughtful recitation of the history and uses of clemency. ${ }^{143}$ The ABA Report makes 11 recommendations for changes in the clemency procedure in Texas. ${ }^{144}$ Texas is not in compliance-or insufficient information is available to determine compliance-in all 11 recommendations. ${ }^{145}$ Most recommendations include open, public, inperson hearings of the Parole Board ${ }^{146}$ considering the facts and circumstances of each case ${ }^{147}$ and all factors which might lead one to conclude death is not appropriate ${ }^{148}$ —giving weight to racial considerations or geographic disparities in the state, ${ }^{149}$ the applicant's mental health, intellectual disability, mental competency, age, ${ }^{150}$ chances of rehabilitation, good behavior while on death row ${ }^{151}$ and residual doubt as to the applicant's guilt. ${ }^{152}$ Additionally, the applicant should have the right to a qualified, sufficiently compensated lawyer with access to investigators, experts, and the time necessary to develop a case for clemency. ${ }^{153}$ Finally, the Board of Pardons and Paroles and the Governor should be trained and the public educated about clemency-as often the last source of relief for one condemned to die-removing "political considerations" from the decision. ${ }^{154}$

A review of the statutes and constitution show no substantive change

\footnotetext{
143. Am. Bar Ass'n, supra note 2, at 253.

144. Id. at 261-89.

145. Id.

146. Id. at 261 (Recommendations \#1 and \#2).

147. Id. at 263 (Recommendation \#3).

148. Id. at 265 (Recommendation \#4).

149. Id. at 267 (Recommendation \#5).

150. Id. at 268 (Recommendation \#6).

151. Id. at 281 (Recommendation \#7).

152. Id. at 268 (Recommendation \#6).

153. Id. at 285 (Recommendations \#8 and \#9).

154. Id. at 287-88 (Recommendations \#10 and \#11).
} 
in this area since 2013. ${ }^{155}$ The Texas Administrative Code also appears unchanged. ${ }^{156}$ Texas still has only granted this relief twice in the modern era. ${ }^{157}$ To its credit, the Texas Board of Pardons and Paroles does provide an online link to clemency application forms and instructions. ${ }^{158}$ The value of a truly independent, effective clemency process was illustrated twice this year.

The case of Duane Buck, discussed under Recommendation \#5, illustrates that in the clemency process the "decision-makers" should consider "patterns of racial ... disparity ...." "159 Mr. Buck's case was one of at least six cases highlighted in 2000 by the then-Attorney General of Texas, wherein improper racial testimony was used at trial. ${ }^{160}$ All of these cases led to new punishment hearings, except for Mr. Buck's. ${ }^{161}$ His clemency request was denied, and he was set for execution in $2011 .{ }^{162} \mathrm{~A}$ reprieve from the Supreme Court came within four hours of being taken to the death chamber ${ }^{163}$ where the clemency process in Texas failed to provide Mr. Buck with a reprieve at that time. ${ }^{164}$ On February 22, 2017, Mr. Buck received a new punishment hearing 17 years after the State of

155. See Tex. Code Crim. Proc. Ann. art. 56.02(a) (LEXIS through 2017 Sess.); TeX. Const. art. IV, §11; TEX. GOV’T CODE § 508.047(b), § 508.115, §551.124, and § 508.0362 (LEXIS through 2017 Sess.).

156. See 37 TeX. Admin. Code AnN. § 143 (LEXIS through 2017 Sess.).

157. See Clemency, DEATH PENALTy INFO. CTR., https://deathpenaltyinfo.org/clemency [http://perma.cc/X7BK-RK6E] (last visited Oct. 21, 2017). Since 1976, clemency was first granted in 1998 for Henry Lee Lucas by Gov. George W. Bush because of his possible innocence and was granted the second time in 2007 for Kenneth Foster by Gov. Rick Perry who "concurred with the 6-1 recommendation from the Texas Board of Pardons and Paroles to commute Foster's death sentence, stating: 'I am concerned about Texas law that allowed capital murder defendants to be tried simultaneously and it is an issue I think the Legislature should examine.' Foster did not kill the victim but drove the car carrying the shooter. He was tried at the same time as the actual shooter, who also received a death sentence. (Associated PRESS, August 30, 2007).” Id.

158. Clemency, TEX. BD. OF PARDONS AND PAROLES, http://www.tdcj.state.tx.us/bpp/exec_clem/exec_clem.html [http://perma.cc/VL49-PAFK] (last visited Oct. 21, 2017).

159. Am. Bar Ass’n, supra note 2, at 267 (Recommendation \#5).

160. Office of the Attorney General News Release Archive, Statement from Attorney General John Cornyn Regarding Death Penalty Cases (June 9, 2000), https://texasattorneygeneral.gov/newspubs/newsarchive/2000/20000609death.htm [http://perma.cc/U8A9-UTLD].

161. Michael Graczyk. Duane Buck Case: U.S. Supreme Court Stays Execution of Texas Inmate, Associated Press, The Philadelphia Sunday Sun (Sept. 23, 2011), http://www.philasun.com/stateside/duane-buck-case-us-supreme-court-stays-execution-of-texasinmate/ [http://perma.cc/24E5-LTWJ].

162. Id.

163. Id.

164. Brandi Grissom, Supreme Court Grants Last-Minute Stay of Duane Buck Execution, THE TEX. TRIBunE (Sept. 15, 2011), https://www.texastribune.org/2011/09/15/victim-prosecutor-senatorbeg-perry-reprieve/ [http://perma.cc/YBN6-GTG4]. 
Texas, through its Attorney General, all but admitted error when the United States Supreme Court granted him relief. ${ }^{165}$ Had the system worked effectively, and within the recommendations of the ABA Report, Mr. Buck's remedy would not have been so long coming. Of course, this case is about race, but it is also about justice delayed because of a failed clemency procedure.

The second recent decision highlighting the need for reform is the case of Marvin Lee Wilson, executed in 2012, who famously cried out to his mother from the gurney that a miracle must have saved him. ${ }^{166}$ It did not. Sadly, all but Wilson's lawyers stood by and allowed Lennie-a fictional character from a John Steinbeck novel-be the measure of a person's intellectual disability. ${ }^{167}$ The system ignored science and permitted Mr. Wilson to be executed despite an I.Q. of $61{ }^{168}$ Just this year, this standard was declared to be in violation of the Eighth Amendment's proscription of cruel and unusual punishments by the United States Supreme Court. ${ }^{169}$

The American Association on Intellectual and Developmental Disabilities (AAIDD) indicted Texas while Mr. Wilson was still alive when they said to the Supreme Court, "[The Texas] impressionistic 'test' directs fact-finders (sic) to use 'factors' that are based on false stereotypes about mental retardation (sic) that effectively exclude all but the most severely incapacitated." ${ }^{170}$ Texas continued to put the intellectually disabled on death row and execute these individuals until the case of Bobby James Moore in 2017. ${ }^{171}$ But, had the politicians heeded the words of the professionals about the Texas standard for measuring intellectual disability, perhaps a thoughtful Governor and Board of Pardons and Paroles in Texas could have granted Marvin Lee Wilson relief, saving him

165. Buck v. Davis, 137 S. Ct. 759, 780 (2017).

166. John Rudolf, Marvin Wilson Execution: Texas Puts Man With 61 IQ to Death, THE HUFFINGTON POST (Aug. 7, 2012), http://www.huffingtonpost.com/2012/08/07/marvin-wilsonexecution-texas_n_1753968.html [http://perma.cc/Q8J5-2CEH].

167. Id. (explaining that each state could decide who qualified as mentally retarded and that Texas used "Lennie” from Steinbeck’s “Of Mice and Men” "as its standard of what type of offender should be exempt from execution").

168. Id.

169. Moore v. Texas, 137 S. Ct. 1039, 1044 (2017).

170. See Intellectual Disabilities: Texas Stands Alone in its Unusual Test of Mental Retardation and Exemption from Execution, DEATH PenAlTy INFO. CTR., https://deathpenaltyinfo.org/intellectual-disabilities-texas-stands-alone-its-unusual-test-mentalretardation-and-exemption-execu [http://perma.cc/XGH6-QFLZ] (last visited Oct. 21, 2017) (quoting the Am. Ass'n on Intellectual and Developmental Disabilities from their brief in Chester v. Thaler.). See also Brief for American Association on Intellectual and Developmental Disabilities as Amici Curiae Supporting Petitioner at 2, Chester v. Thaler, 586 U.S. 978 (2012) (No. 11-1391).

171. Moore, 137 S. Ct. at 1044. 
from his child-like reaction to the length of his execution and the shameful hope he must have felt as his life left him on that gurney. The AAIDD felt that it would require the Supreme Court's intervention to change the Texas approach. ${ }^{172}$ The Supreme Court has now directed Texas to follow "current medical standards" and by doing so invites the politicians of Texas to use science and reasoning ${ }^{173}$-the same duo which would revolutionize the Texas clemency process.

\section{Capital Jury Instructions}

Chapter Ten makes six recommendations to improve capital jury instructions applicable to Texas. ${ }^{174}$ Many of these recommendations appear to be applicable to all death penalty states, not just Texas. For example, Recommendation \#1 is a suggestion that instructions should be written by professionals in other disciplines - those other than lawyerswith input from lawyers to improve jurors' understanding of the instructions and the law. ${ }^{175}$ For decades, studies have shown that jurors do not understand instructions, make assumptions of guilt and punishment prior to hearing the evidence, assign improper standards to their decisions, and basically fail to abide by the law. ${ }^{176}$ The lawyers that have composed the jury instructions in Texas have produced excellent documents that other lawyers have dissected and reviewed for legal defects, to no avail. Our profession is woefully blind to the fact that statistics show that the population from which juries are chosen have a wide variety of educational backgrounds and have limited ability to understand our complicated instructions. When we pretend that a jury pool understands the instructions because we, the lawyers, understand them, we suffer a humorous fallacy in logic.

Recommendations \#2 and \#3 are followed in practice in Texas. ${ }^{177}$

172. Brief for Am. Ass'n on Intellectual and Developmental Disabilities as Amici Curiae Supporting Petitioner at 20, Chester v. Thaler, 586 U.S. 978 (2012) (No. 11-1391).

173. Moore, 137 S. Ct. at 1048-49.

174. Am. Bar Ass'n, supra note 2, at 291 (Chapter Ten, Capital Jury Instructions). The ABA Report makes a seventh recommendation but it is not applicable in Texas and is not considered here. Id. at 322.

175. Id. at 297 .

176. William J. Bowers \& Wanda D. Foglia, Still Singularly Agonizing: Law’s Failure to Purge Arbitrariness from Capital Sentencing, 39 CRIM. L. BULL. 51, 54 (2003).

177. Am. Bar Ass'n, supra note 2, at 300 (explaining that Recommendation \#2 is that "jurors should receive written copies of 'court instruction' . . to consult while the court is instructing them and while conducting deliberations.” See TEX. CODE CRIM. PROC. ANN. art. 36.18 (LEXIS through 2017 Sess.)). See also Am. Bar Ass'n, supra note 2, at 301 (explaining that Recommendation \#3 suggests courts should respond meaningfully to questions from the jury. See TEX. CODE CRIM. PROC. ANN. art. 36.27 (LEXIS through 2017 Sess.)). 
Articles 36.18 and 36.27 of the Texas Code of Criminal Procedure address these two issues and all courts, to my knowledge, follow the instructions of these rules. Most courts in Texas give a copy of the jury instructions to each juror as the court reads them. During deliberations, jury questions are most often answered with an instruction to follow the instructions formerly given by the court, and the juries most often communicate with the court as instructed. These rules have been the law in Texas since 1965. ${ }^{178}$

Recommendation \#4 speaks of telling the jury about alternative punishments and allowing testimony of parole practices to assist jurors' understandings. ${ }^{179}$ There are no alternative punishments in Texas. ${ }^{180}$ One receives either life without parole or death if convicted of a capital crime. ${ }^{181}$ As to discussion of parole issues, unless the convicted was under 18 at the time of the offense, there are no parole issues, and it certainly would be discretionary for a trial court to allow such testimony should counsel be able to make it relevant. ${ }^{182}$

Recommendation \#5 suggests courts not place limits on a jury's ability to give full consideration to any evidence which favors life, not death. ${ }^{183}$ This portion of the chapter discusses Texas's future dangerousness special issue, predictions of future dangerousness and the experts that give those predictions, selection of a death-qualified jury, other sentencing special issues, and the failure to instruct on residual doubt and mercy. ${ }^{184}$ The Texas sentencing statute has not changed substantively since the ABA Report. ${ }^{185}$ Therefore, Texas has not followed any of the ABA Report's recommendations and their discussion provides no solutions. However, there are a few areas in which this statute could be improved.

First, as suggested, Texas must stop lying to juries. ${ }^{186}$ Whenever a

178. See Tex. Code Crim. Proc. art. 36.18 (LEXIS through 2017 Sess.).

179. Am. Bar Ass'n, supra note 2, at 303.

180. See TEX. Penal Code ANn. § 12.31(a) (LEXIS through 2017 Sess.) For those 18 or older, the punishment when death is sought is either life in prison without parole or death. Should the accused be younger than 18 at the time of the offense or death not be sought, specific provisions of this section are applicable. Id.

181. Id.

182. Sells v. State, 121 S.W.3d 748, 756 (Tex.Crim.App. 2003).

183. Am. Bar Ass'n, supra note 2, at 307.

184. Am. Bar Ass'n, supra note 2, at 307-18.

185. See Tex. Code Crim. Proc. AnN. art. 37.071 (LEXIS through 2017 Sess.).

186. Am. Bar Ass'n, supra note 2, at 316. See TEX. CodE Crim. Proc. ANN. art. 37.071, § 2(d)(2) (LEXIS through 2017 Sess.) (requiring a unanimous vote for a "yes" answer to the special issues on future dangerousness and parties found in TEX. CODE CRIM. PROC. ANN. art. 37.071, § 2(b) and forbidding a jury from answering any of those issues "no" unless 10 or more jurors agree); id. § 
jury is told a 10 to 2 vote will effect one result and a unanimous vote will effect another result, this is just a lie. A unanimous vote will always bring about the result agreed upon, but it is common knowledge in the Death Penalty Community in Texas that only one person can vote "no" on the first two special issues or "yes" on the third special issue and the defendant will receive life through a hung jury-just no one can talk about it. Interestingly, there was a Bill introduced during the 2017 Texas Legislative Session that addressed this issue. ${ }^{187}$ The Bill was reported out of committee and died waiting to be placed on the Calendar. It is interesting to note the committee voted 6 in favor and only 1 against, which is remarkable. This Bill would have removed the 10 to 2 lie and, in its original version, allow for a jury to be told the effect of failure of the jury to agree on the second and third special issues. This would have virtually ended the death penalty in Texas, removing confusion and empowering even one juror with the ability to secure a life punishment with just their vote, and empower the defense to talk about it. So there is hope.

The last recommendation in this chapter would allow juries to be instructed that a "juror may return a life sentence, even in the absence of any mitigating factor and even where an aggravating factor has been established beyond a reasonable doubt, if the juror does not believe that the defendant should receive the death penalty." ${ }^{188}$ This recommendation would require a complete sea change in the Texas scheme. Needless to say, this has not been implemented, or even discussed to my knowledge.

\section{J. Judicial Independence and Vigilance}

There are six recommendations in the ABA Report to improve the judicial function in capital cases. ${ }^{189}$ Recommendations \#1, \#2, \#4, and \#5 include changing the partisan election of judges, educating the public about judicial independence, recusal of judges who have made prejudgment statements, and judges taking immediate action to address prosecutorial misconduct or ineffectiveness by the defense. ${ }^{190}$ There is no

2(f)(2) (requiring a unanimous vote for a "no" answer to the mitigation special issue found in id. § 2(e)(1) and forbidding a jury from answering "yes" unless 10 or more jurors agree); id. § 2(a)(1) (LEXIS through 2017 Sess.) ("The court, the attorney representing the state, the defendant, or the defendant's counsel may not inform a juror or a prospective juror of the effect of a failure of a jury to agree on issues submitted ....”).

187. See H.B. 3054, 85th Leg., Reg. Sess. (Tex. 2017).

188. Am. Bar Ass'n, supra note 2, at 320.

189. Id. at 323.

190. Id. 
movement in reforming these problems. Judges in Texas still run for office and advocate their stance as being tough on crime, and apparently the public expects it. One reform would be making the reporting of misbehavior or unprofessional conduct in a courtroom a responsibility of all the officers of the court. As stated above, the Texas criminal system will not improve until sanctions, such as misprision, follow the intentional overlooking of serious professional malfeasance. ${ }^{191}$

Sadly, Judge Elsa Alcala of the Texas Court of Criminal Appeals announced she would not seek re-election. ${ }^{192}$ Judge Alcala has been a voice of reason on the death penalty. Most notably, just this year Judge Alcala dissented in the cases of Bobby James Moore and Duane Buck, both granted relief from the United States Supreme Court, who agreed with Judge Alcala's judgment. ${ }^{193}$ It is the continuous nature of a statewide partisan election which the Judge cites as her primary reason for quitting. ${ }^{194}$

To its credit, Texas does provide a mechanism for hearing complaints against judges. The State Commission on Judicial Conduct "is responsible for investigating allegations of judicial misconduct or judicial disability, and for disciplining judges." ${ }^{195}$ Although the punishments seldom are harsh, the Commission does actively carry out its mission. ${ }^{196}$

The ABA Report complains that fault also lies with the State Bar of Texas for failing to implement its 2012 Strategic Plan "to educate the public about the Rule of Law and the role of judges, lawyers, and the public in the justice system.” ${ }^{197}$ In the Bar’s Strategic Plan FY 2018 and FY 2019, these goals are again stated as the first goal of the Bar. ${ }^{198}$ The State Bar actually goes to great length to educate the public. Just a short time on the Bar's website shows a wide variety of resources available to

191. See supra, note 116, as to prosecutorial misconduct.

192. Meagan Flynn, Texas Judge Elsa Alcala, Who Criticized Death Penalty, Won't Seek Reelection, Hous. PRESS (Dec. 30, 2016), http://www.houstonpress.com/news/texas-judge-elsa-alcalawho-criticized-death-penalty-wont-seek-re-election-9067899 [http://perma.cc/K5ZV-GJRS].

193. Id.

194. Id.

195. Texas, STATE COMM'N ON JUdICIAL CONDUCT, http://www.scjc.texas.gov/ (last visited Oct. 21, 2017).

196. Disciplinary Actions, STATE COMM’N ON JUDICIAL CONDUCT, http://www.scjc.texas.gov/disciplinary-actions/ [http://perma.cc/7EHZ-GA3Y] (last visited Oct. 23, 2017). At the Commission's website are the cases of judges investigated and punished by the Commission.

197. Am. Bar Ass'n, supra note 2, at 330 (quoting the State Bar of Texas, State Bar of Texas Strategic Plan: FY2012 \& FY2013, at 3 (2012)).

198. State Bar of Texas, State Bar of Texas Strategic Plan: FY2018 \& FY2019, at 3 (2017), https://www.texasbar.com/AM/Template.cfm?Section=Our_Mission\&Template=/CM/ContentDispl ay.cfm\&ContentID=11010 [http://perma.cc/V9FY-MRXC]. 
lawyers and non-lawyers designed to address this concern. ${ }^{199}$ The ABA Report appears to be a bit short in its criticism of the lawyers of Texas when it comes to education of the public. Additionally, Recommendation \#3 puts the burden on bar associations and community leaders to speak out against those that attack judges for their decisions in capital cases. ${ }^{200}$ This criticism may well be justified. Politics in judicial elections does give a chilling effect to both public criticism and support of the judiciary. But, non-partisan election of judges has not proven itself to be effective in eliminating the political side effects of partisanship. ${ }^{201}$

Recommendation \#6 states judges should ensure full discovery in capital cases. ${ }^{202}$ This recommendation has been fully implemented with the passage of the amendments to article 39.14 of the Texas Code of Criminal Procedure-known as the Michael Morton Act, as discussed above in Section D: Prosecution. ${ }^{203}$

\section{K. Racial and Ethnic Minorities}

The ABA Report makes ten recommendations toward the goal of eliminating "race and ethnicity as a factor in the administration of the death penalty." ${ }^{204}$ The State should (1) investigate racial discrimination, (2) evaluate discrimination's impact on the justice system, (3) develop strategies to address it, (4) collect data on these issues from the initial report through execution of sentence, (5) collect empirical data for study, (6) pass legislation allowing inmates to challenge their conviction obtained with improper discriminatory patterns, (7) develop appropriate educational and training programs, (8) sanction state actors guilty of discrimination, (9) ensure a fair judiciary by the use of recusal of judges showing discriminatory decision making, and (10) eliminate procedural bars to claims of racial discrimination at any point in the judicial process. ${ }^{205}$

Texas periodically addresses specific racial issues through

\footnotetext{
199. See generally State Bar of Texas (2017), https://www.texasbar.com/ [http://perma.cc/7J7C-33RB].

200. Am. Bar Ass'n, supra note 2, at 335.

201. See Layne S. Keele, Why the Judicial Elections Debate Matters Less Than You Think: Retention as the Cornerstone of Independence and Accountability, 47 AKRON L. REV. 375, 377 (2014) (arguing that we do not elect judges, we decide on their retention); Paul J. De Muniz, Politicizing State Judicial Elections: A Threat to Judicial Independence, 38 WILLIAMETTE L. REV. 367, 367-68 (2002) (providing a less than flattering history of the non-partisan election of judges in Oregon).

202. Am. Bar Ass'n, supra note 2, at 343.

203. Supra, Section D Prosecution, at 18.

204. Am. Bar Ass'n, supra note 2, at 347.

205. Id. at 351-76.
} 
legislation or rules - the use of a prohibition against racial profiling, ${ }^{206}$ prohibiting lawyers from racial bias or prejudice, ${ }^{207}$ forbidding the exercising of preemptory challenges in jury selection based on race, ${ }^{208}$ not allowing the introduction of a defendant's race to show propensity toward criminal conduct in the future, ${ }^{209}$ or finding that an offense was committed because of bias or prejudice. ${ }^{210}$ But, the solution to these issues rests in the judiciary. Ultimately, the U.S. Supreme Court must stop avoiding the issue of race "in its foundational constitutional cases .... [T] [Te Court [has] consistently avoided direct engagement with the issue of racial discrimination in capital punishment." ${ }^{211}$ The Texas Legislature and Texas Courts will address the issues raised by the ABA Report as to race and ethnicity when the U.S. Supreme Court finally stops its procedural tinkering with the mechanism of death and declares the process unconstitutional and beyond our ability to correct.

\section{Intellectual Disability and Mental Illness}

The ABA Report proffers 7 recommendations as to intellectual disability and 13 as to mental illness. ${ }^{212}$ No summary of the recommendations as to intellectual disability are necessary as Texas must now re-evaluate how it handles death penalty cases involving those alleged or found to be intellectually disabled in light of the recent Supreme Court decision in the case of Bobby James Moore, as discussed above under the section on clemency. ${ }^{213}$ Science must now take its place in Texas jurisprudence as the courts must now consult current medical standards to determine intellectual disability. ${ }^{214}$ In the near future, we will train the lawyers, judges, court personnel, law enforcement, and corrections on the new procedure to be developed to establish, rebut, and treat the intellectually disabled charged with a capital murder. It is to this end the Moore decision has forced Texas into a new era.

206. TeX. Code Crim. Proc. AnN. art. 2.131 (LEXIS through 2017 Sess.).

207. Tex. Disciplinary R. of Prof'l Conduct R. 5.08(a) (2016), https://www.texasbar.com/AM/Template.cfm?Section=Home\&Template=/CM/ContentDisplay.cfm \&ContentID=27271 [http://perma.cc/DM42-S6QC].

208. Tex. Code CRIM. Proc. ANN. art. 35.261 (LEXIS through 2017 Sess.).

209. Id. at art. 37.071.

210. Id. at art. 42.014 (a). See Tex. Penal Code AnN. § 12.47 (LEXIS through 2017 Sess.) (increasing the punishment after a finding under TEX. Code CrIM. Proc. AnN. art. 42.014.)

211. Symposium, The American Death Penalty and the (In)Visibility of Race, 82 U. CHI. L. Rev. 243, 243-94 (2015).

212. Am. Bar Ass'n, supra note 2, at 379-444.

213. See Moore v. Texas, 137 S. Ct. 1039, 1049 (2017).

214. Id. at 1048 . 
Finally, 13 recommendations were made in the ABA Report on issues involving mental illness. ${ }^{215}$ Texas was not in full compliance with any of the recommendations and so it remains. ${ }^{216}$ However, Texas does not ignore the issues associated with mental health. As to training and education, organizations such as the National Alliance on Mental Health Texas, ${ }^{217}$ Mental Health America of Texas, ${ }^{218}$ the Hogg Foundation for Mental Health, ${ }^{219}$ and Disability Rights Texas ${ }^{220}$ are just a few of the private organizations that provide or have provided training, services, advocacy, and information on mental health issues. The Texas Department of State Health Services is requesting over \$3 billion dollars per year for the next two years to spend on a wide variety of health services, including mental health. ${ }^{221}$ As per Recommendations \#1, \#3, and \#13, all individuals that deal with capital cases must be trained on how to recognize and handle the mentally ill. Defense lawyers, prosecutors, and judges receive regular training - even though it may be inadequate in many respects. ${ }^{222}$ Other training is available to law enforcement, correctional personnel, and other mental health providers through the Texas CIT Association ${ }^{223}$ and the Texas Commission on Law

215. Am. Bar Ass'n, supra note 2, at 419-44.

216. Id. at xlvii.

217. About Us, NAMI TEX., https://namitexas.org/about-us/ [http://perma.cc/A9ED-GU8G] (last visited Oct. 21, 2017).

218. MENTAL HeALTH AM. OF TEX., http://www.mhatexas.org/ [http://perma.cc/MB7H-ALSE] (last visited Oct. 21, 2017).

219. Texas Mental Health Code Project, Hogg Found. FoR Mental HeAlth, http://hogg.utexas.edu/new-resources/texas-mental-health-info [http://perma.cc/T928-Q7GH] (last visited Oct. 21, 2017).

220. DisABILITY RIGHTS TEX., http://www.disabilityrightstx.org/ [http://perma.cc/6YBPK6WM] (last visited Oct. 21, 2017).

221. FY 2018-2019 Legislative Appropriations Request, TEX. HEALTH AND HuMAN SERVICES, https://www.dshs.texas.gov/budget/lar/default.aspx [http://perma.cc/2WSJ-BEZ4] (last visited Oct. 27, 2017).

222. E.g., News from Texas Tech University School of Law, Law Review \& Administrative Law Journal Host Mental Health Law Symposium, SIDEBAR (Nov. 2016), http://techlawnews.law.ttu.edu/?p=6165 [http://perma.cc/TEJ2-J5Q8]; The Annual Judicial Education Conference put on by the Texas Center for the Judiciary with breakout sessions on mental health issues and trends in capital cases, see Annual Educ. Judicial Conference, TEX. CTR. FOR THE JUDICIARY,

http://www.yourhonor.com/web/Online/Events/Event_Display.aspx?EventKey=17ANNUAL [http://perma.cc/T4RJ-ZBNU] (last visited Oct. 21, 2017) (cancelled for 2017). The State Bar of Texas also provides many opportunities for training through its website and the seminars it produces, see STATE BAR OF TEX., http://www.texasbarcle.com/CLE/Home.asp [http://perma.cc/QM7GWBNX] (last visited Oct. 21, 2017). The problem is not the availability of training. Getting the lawyers to attend the training is the issue.

223. See FAQ, TEX. CIT Ass’n, http://www.texascit.org/faq.php [http://perma.cc/7GG2-2TCN] (last visited Oct. 21, 2017): 
Enforcement. $^{224}$

As to Recommendation \#2 (interrogating the mentally ill), \#3 (appointment of qualified lawyers with resources), and \#4 and \#5 (use of experts), Texas Courts control most of these matters guided only by their own discretion and political survival instincts. Nothing new has occurred since the ABA Report.

Recommendations \#6 and \#7 have brought about no changes in the willingness of Texas to forego the execution of the mentally ill. ${ }^{225}$ Recommendations \#8 and \#9 are to jury instructions. ${ }^{226}$ Suffice it to say, the requested instructions as to mental illness recommended by the ABA Report have not been implemented. ${ }^{227}$

Recommendation \#10 suggests the implementation of a "next friend" system to allow the mentally ill the assistance of a person, paid by the court, to make decisions in the appellate, habeas, and clemency process to help prevent the mentally ill from waiving important procedural and substantive rights. ${ }^{228}$ Much as Texas has provided for the appointment of

The Crisis Intervention Team (CIT) program is a model community initiative designed to improve the outcomes of police interactions with people living with mental illnesses. CIT programs are built on local partnerships between law enforcement agencies, mental health providers and advocates (local NAMI Affiliates). They involve individuals living with mental illnesses and families at all levels of decision-making and planning. CIT programs typically provide 40 hours of training for law enforcement on how to better respond to people experiencing a mental health crisis. Equally important, CIT programs provide a forum for partner organizations to coordinate diversion from jails to mental health services. In many communities, CIT has served as a springboard for a broader collaboration between the criminal justice and mental health systems. Many CIT programs have included partners from the juvenile justice system, courts, corrections, homeless services, children's mental health services, the Veterans Administration and others. Many CIT programs have begun to offer trainings to correctional officers, dispatchers, EMTs, firefighters, school resource officers, hospital safety officers and others. There are also CIT programs that offer trainings focused on responding to youth and veterans.

224. Training and Instruction, TEX. COMM'N ON LAW ENF'T, http://www.tcole.texas.gov/content/training-and-instruction [http://perma.cc/RBZ7-QVQ7] (last visited Oct. 27, 2017).

225. Am. Bar Ass'n, supra note 2, at 426 (Recommendations \#6 and \#7). See Marc Bookman, How Crazy is Too Crazy to be Executed?, MOTHER JONES (Feb. 12, 2013), http://www.motherjones.com/politics/2013/02/andre-thomas-death-penalty-mental-illness-texas [http://perma.cc/6WHS-3J3T]. This unfortunate story is about Andre Thomas who committed unspeakable crimes and blinded himself while waiting execution. Mr. Thomas remains on death row. See Death Row Information, TEX. DEP'T OF CRIMINAL Justice, https://www.tdcj.state.tx.us/death_row/dr_offenders_on_dr.html [http://perma.cc/G3LP-ANH4] (last visited Oct. 21, 2017).

226. Am. Bar Ass'n, supra note 2, at 431, 434.

227. See supra, Section I, at 32, and the discussion of Capital Jury Instructions.

228. Am. Bar Ass'n, supra note 2, at 436. The ABA Report also cites Tex. R. Civ. Proc. 44 as to the appointment of guardian ad litems in civil matters and case law that appears to authorize appointment of next friends in Federal Court. Am. Bar Ass'n, supra note 2, at 437 nn. 455-56 (citing 
a guardian ad litem for a child in addition to their attorney ad litem, this "next friend" system would provide an additional decision-maker for the mentally ill. ${ }^{229}$

The final Recommendations \#11 and \#12 deal with the person condemned to die whose mental illness is so severe that it renders that person incompetent to assist in post-conviction proceedings and eventually incompetent to be executed-and with the corresponding issues of staying both the post-conviction proceedings or a planned execution, and the suggested reduction of a death sentence to life in prison without parole for one who will never be restored to competence. ${ }^{230}$ The ABA Report discusses in length the limitations of the Texas postconviction habeas statute ${ }^{231}$ and the statute defining competency to be executed. ${ }^{232}$ Analyzing Ford v. Wainwright, ${ }^{233}$ in light of Panetti $v$. Quarterman, ${ }^{234}$ the ABA Report carefully outlines the procedures for execution competence showing first the statute is unconstitutional and then somehow constitutional even in light of the requirements of Panetti. ${ }^{235}$ Even though several changes in Texas law were suggested, none have been implemented. ${ }^{236}$

\section{CONCLUSION}

Those that worked on the ABA Report provided a worksheet to repair the Texas death penalty system. The ABA Report makes 93 recommendations covering 12 different subjects. Each chapter itself is overwhelming in its particularity. Texas, to its credit, has made significant

Whitmore v. Arkansas, 495 U.S. 149, 164-65 (1990); Harper v. Parker, 177 F.3d 567, 569 (6th Cir. 1999) and Rees v. Peyton, 384 U.S. 312, 314 (1966)). Texas Juvenile Law provides for guardian ad litems to act for a child when a parent cannot or will not act in the child's best interest. TEX. FAM. CODE ANN. § 51.11 (LEXIS through 2017 Sess.).

229. TEX. FAM. CODE ANN. § 51.11 (LEXIS through 2017 Sess.). Texas Juvenile Law provides for the appointment of a guardian ad litem to act for a child when a parent cannot or will not act in the child's best interest.

230. Am. Bar Ass'n, supra note 2, at 438-39.

231. See Tex. Code Crim. Proc. AnN. art. 11.071 (LEXIS through 2017 Sess.). No substantive changes in the statute since the ABA Report was issued.

232. See id. at art. 46.05. No substantive changes in the statute since the ABA Report was issued.

233. Ford v. Wainwright, 477 U.S. 399 (1986).

234. Panetti v. Quarterman, 551 U.S. 930 (2007).

235. Am. Bar Ass'n, supra note 2, at 438-44.

236. No substantive changes in TEX. CODE CRIM. PROC. ANN. art. 46.05 (LEXIS through 2017 Sess.) since the ABA Report. A check of Texas Legislature Online shows no Bills are pending in the current legislative session amending any of the provisions of TEX. CODE CRIM. PRO. ANN. art. 46.05. See Search Results, TeX. LEGISLATURE OnLINE, http://www.capitol.state.tx.us/Home.aspx [http://perma.cc/ZY5V-VWZT] (last visited Oct. 21, 2017) (select “85(1) - 2017” under Legislature; then select “Word/Phrase;” then search “46.05”). 
progress. Here are just a dozen of the progressive measures Texas has fostered since the date of the ABA Report:

(1) Texas created The Timothy Cole Exoneration Review Commission which produced a report in December 2016, ${ }^{237}$ continuing the work of the Timothy Cole Advisory Panel on Wrongful Convictions Report of $2010,{ }^{238}$ addressing issues such as eyewitness identification, interrogations, informant testimony, and forensic science;

(2) The Texas Legislature added substantive changes in 2013 and 2015 to the work of the Texas Forensic Science Commission, including, among other things, removing the Director of the Department of Public Safety from the accreditation process of forensic laboratories, while creating a process to license forensic analysts; ${ }^{239}$

(3) Texas passed the Michael Morton Act and made significant new changes to the Texas discovery process by amending article 39.14 of the Texas Code of Criminal Procedure; ${ }^{240}$

(4) Texas created mandatory training for prosecutors on their duty to disclose exculpatory and mitigating evidence; ${ }^{241}$

(5) Texas created and continued to provide financial support for the Regional Public Defender for Capital Cases, the Office of Capital and Forensic Writs, the Texas Indigent Defense Commission, and the proposed Office of the Capital Appellate Defender; ${ }^{242}$

(6) Texas financially supports its many state agencies that set policy, train, and monitor the licensing of law enforcement, judges, and lawyers and that provide a platform for citizens to lodge complaints against them; ${ }^{243}$

(7) Texas is now beginning to hold prosecutors accountable for allegations of misconduct; ${ }^{244}$

(8) Texas just passed House Bill 1253 in the current 85th Regular Legislative Session as to the electronic recording of interrogations

237. Timothy Cole Exoneration Review Comm'n, supra note 17.

238. Timothy Cole Advisory Panel on Wrongful Convictions, supra note 99.

239. TeX. Code Crim. Proc. AnN. art. 38.01 (LEXIS through 2017 Sess.).

240. Supra, Recommendation \#3: Discovery under Section 4. Prosecution, at 18.

241. TeX. Gov’T CODE ANN. § 41.111 (LEXIS through 2017 Sess.), H.B. 1847, 83rd Leg., Reg. Sess. (Tex. 2013).

242. Texas Legislature, supra note 121.

243. Fiscal Size-up 2016-17 Biennium, 327-96, Legislative Budget BD. (2016), http://www.lbb.state.tx.us/Documents/Publications/Fiscal_SizeUp/Fiscal_SizeUp.pdf [http://perma.cc/77AV-T69S].

244. E.g., Chammah, supra note 109. 
completing the work of the Timothy Cole Advisory Panel on Wrongful Convictions; ${ }^{245}$

(9) The Texas House passed House Bill 3054 in the current 85th Regular Legislative Session eliminating the "10-2 lie" and the "hung jury lie" in Texas's capital special issues (although this Bill did not make it through the Senate in this session); ${ }^{246}$

(10) The State Bar of Texas Strategic Plan FY 2018 and FY 2019 makes the education of the public as the first goal of the Bar; ${ }^{247}$

(11) The U.S. Supreme Court decision in Moore v. Texas now forces Texas to consult current medical standards to determine intellectual disability for those accused of capital murder; ${ }^{248}$ and

(12) The tireless work of the many public and private organizations and individuals that train, educate, provide services, and advocate for those with mental health issues. ${ }^{249}$

Those are just a dozen areas in which Texas has made great progress. But fail not, even as the number of those on death row in Texas is falling, ${ }^{250}$ and executions nationwide are in free-fall, ${ }^{251}$ the death penalty is not being abandoned. The encouraging drop in the death row population is associated with the significant decrease of those arriving on death row from the trial courts. ${ }^{252}$ The passion to execute seems to be waning as empirical evidence continues to fail to substantiate deterrence as the

\footnotetext{
245. S.B. 1253, 85th Leg., Reg. Sess. (Tex. 2017).

246. H.B. 3054, 85th Leg., Reg. Sess. (Tex. 2017).

247. State Bar of Texas, supra note 198.

248. Moore v. Texas, 137 S. Ct. 1039, 1048 (2017).

249. E.g., NAMI Texas, supra note 217.

250. See Am. Bar Ass'n, supra note 2, at 1. See also Gender and Racial Statistics of Death Row Offenders, TEX. DEP'T OF CRIMINAL JUSTICE, http://www.tdcj.state.tx.us/death_row/ dr_gender_racial_stats.html [http://perma.cc/E433-5KSZ] (last visited Oct. 21, 2017). As of August 2013, Texas had 278 inmates on death row. Of those, 269 were males and 9 were females, 110 African-American, 82 White, 82 Hispanic, and 4 fell into the "other" race category. As of today, Texas has 233 inmates on death row. Of those, 227 are males and 6 are females, 102 AfricanAmerican, 63 White, 63 Hispanic and 5 of “other" races. These statistics show the number on death row in Texas has fallen by about $16 \%$ during this period, the male to female ratio is about the same, and the percentage of Whites and Hispanics has dropped, while the percentage of the African American population has grown by $4 \%$ compared to the total population on death row. Id.

251. Fact Sheet, DEATH PENALTY INFO. CTR., https://deathpenaltyinfo.org/ documents/FactSheet.pdf [http://perma.cc/P8DH-GR7V] (last visited Oct. 21, 2017) (chart showing nationwide executions since 1976).

252. Death Sentences in the United States from 1977 by State and by Year, DeATH PENALTY INFO. CTR., http://www.deathpenaltyinfo.org/death-sentences-united-states-1977-present [http://perma.cc/MV5V-QKQZ] (last visited Mar. 19, 2017).
} 
primary justification for a death penalty option. ${ }^{253}$ Whether it is the continued exoneration of the innocent, ${ }^{254}$ the financial burden of capital punishment, ${ }^{255}$ or the recognition that alternatives to the death penalty are available of which the public approves, ${ }^{256}$ the number of souls on death row or removed from death row by execution continues to decrease. So, this raises the question, how low will the numbers fall?

Texas and the more active death penalty states will most likely reach an equilibrium rather than eliminate the option by failing to use it. In Texas, the average number of death sentences during the last ten years was eight per year, as seen in the graph below. ${ }^{257}$ If 2015 and 2016 were outliers, the average death sentences in Texas has been about nine new sentences a year. ${ }^{258}$ In a state the size of Texas, with such a storied history of enjoying the execution option, a consistent number of this size seems to be inevitable. ${ }^{259}$

253. Committee on Deterrence and the Death Penalty, Deterrence and the Death Penalty, NAT’L RESEARCH COUNCIL, 2 (2012), https://www.nap.edu/download/13363 [http://perma.cc/LCT2KPBE]. The Committee found:

[T] hat research to date on the effect of capital punishment on homicide is not informative about whether capital punishment decreases, increases, or has no effect on homicide rates. Therefore, the committee recommends that these studies not be used to inform deliberations requiring judgments about the effect of the death penalty on homicide. Consequently, claims that research demonstrates that capital punishment decreases or increases the homicide rate by a specified amount or has no effect on the homicide rate should not influence policy judgments about capital punishment. Id.

254. See The Innocent List, DEATH PENALty INFo. CTR., https://deathpenaltyinfo.org/innocence-list-those-freed-death-row [http://perma.cc/339J-2WWE] (last visited Oct. 21, 2017) (showing 160 souls have been exonerated off death row in the modern era). See also Michael McLaughlin, Shocking Number Of Innocent People Sentenced To Death, Study Finds, THE HUFFINGTON POST (Apr. 28, 2014), http://www.huffingtonpost.com/2014/04/28/innocent-death-penalty-study_n_5228854.html [http://perma.cc/8QVJ-AU37].

255. Kelly Phillips Erb, Death and Taxes: The Real Cost of the Death Penalty, ForBes (Sept. 22, 2011), https://www.forbes.com/sites/kellyphillipserb/2011/09/22/death-and-taxes-the-real-costof-the-death-penalty/\#7829d472673e [http://perma.cc/55GW-UNR4]. See also Metze, supra note 91, at 326-27 nn. 520-23.

256. Baxter Oliphant, Support for Death Penalty Lowest in More Than Four Decades, PEW RESEARCH CTR. (Sept. 29, 2016), http://www.pewresearch.org/fact-tank/2016/09/29/support-fordeath-penalty-lowest-in-more-than-four-decades/ [http://perma.cc/TD6D-8MSE] (showing the support for the death penalty was at 49\%). See also Damla Ergun, New Low in Preference for the Death Penalty, ABC NEws (June 5, 2014), http://abcnews.go.com/blogs/politics/2014/06/new-lowin-preference-for-the-death-penalty/ [http://perma.cc/N5H9-6PU7] (explaining that 52\% of Americans prefer life in prison without parole, compared to $42 \%$ who favor the death penalty).

257. See Fact Sheet, DeATH PENALTY INFO. CTR., supra note 251.

258. Id.

259. See id. The death penalty is not dying of its own design. I continue to teach capital punishment law to my students with the caveat that they should prepare to continue the fight as those that have fought this for a lifetime are disappearing. It is time to train a new generation of capital 


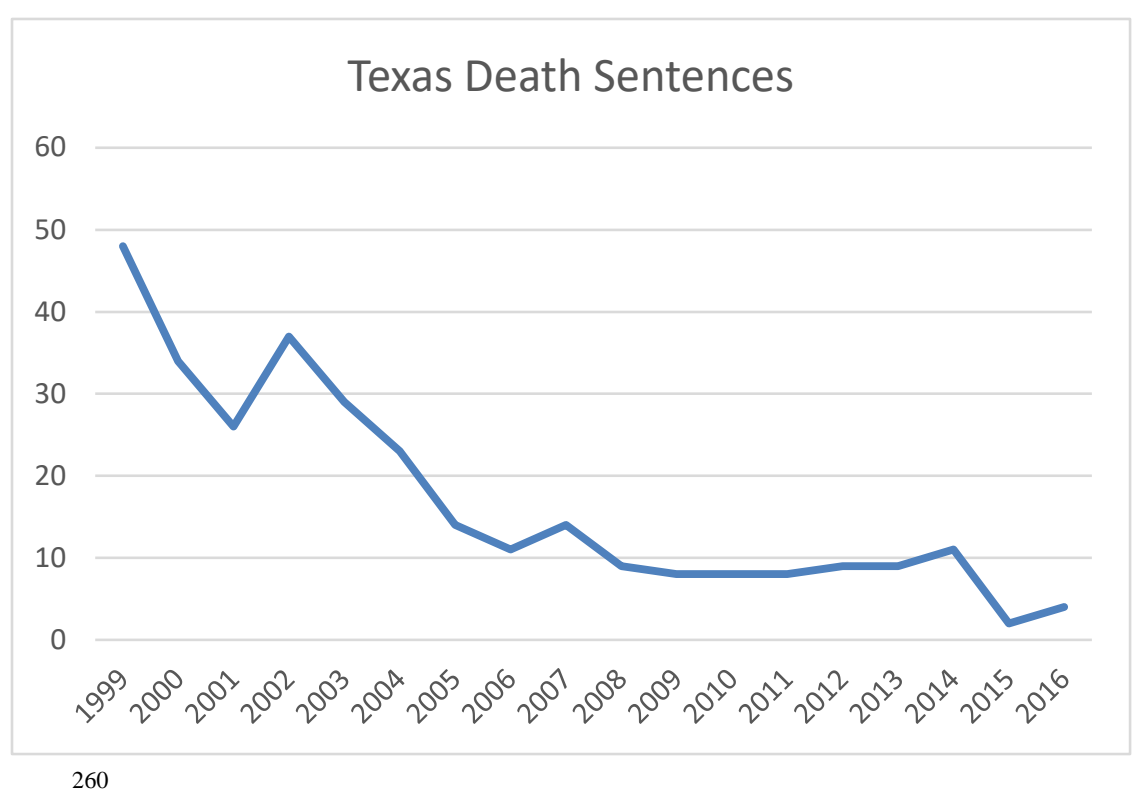

The only hope in elimination of the death penalty in Texas is the slow drip of procedural oversight by the U.S. Supreme Court. In 2015, hopes were never higher for the end to the death penalty. That year, death sentences in Texas had almost disappeared. And then, in October of 2015, came the following words from Pope Francis spoken directly to the leaders of the United States in a joint session of Congress:

The Golden Rule also reminds us of our responsibility to protect and defend human life at every stage of its development. This conviction has led me, from the beginning of my ministry, to advocate at different levels for the global abolition of the death penalty. I am convinced that this way is the best, since every life is sacred, every human person is endowed with an inalienable dignity, and society can only benefit from the rehabilitation of those convicted of crimes. Recently my brother bishops here in the United States renewed their call for the abolition of the death penalty. Not only do I support them, but I also offer encouragement to all those who are convinced that a just and necessary punishment must never exclude the dimension of hope and the goal of

defenders.

260. See generally DeATH PenALTY INFO. CTR., supra note 257. 
rehabilitation. $^{261}$

Sitting in that room were the pillars of our government and members of a church which has 1.2 billion in its membership. ${ }^{262}$ In the front row, directly in front of the speaker, were Chief Justice Roberts and Associate Justice Kennedy of the Supreme Court, both Catholic, both conservative, and both surely conflicted. ${ }^{263}$ When the Bishop of Rome, Vicar of Jesus Christ, Pope Francis, spoke those words that night, our leaders were listening. Some believe Justice Kennedy has been on the edge of joining his liberal Justices to end the death penalty, ${ }^{264}$ and some were hoping he would do so when Justice Roberts joined him. Their presence together that evening was not a coincidence. Now, with the rumored retirement of Justice Kennedy, and the current political climate in Washington, Kennedy's replacement ${ }^{265}$ will certainly move the court even further to the right making an 8th Amendment solution virtually impossible for another generation. ${ }^{266}$ All hopes are gone.

So, I finish this article as I began; wondering what good is a society that turns away from those facing a death sentence, shutting itself off from

261. Ryan Teague Beckwith, Transcript: Read the Speech Pope Francis Gave to Congress, TiME (Sept. 24, 2015), http://time.com/4048176/pope-francis-us-visit-congress-transcript/ [http://perma.cc/8WY3-DWZM].

262. Peter Baker \& Jim Yardley, Pope Francis, in Congress, Pleads for Unity on World's Woes, THE N.Y. TIMES (Sept. 24, 2015) https://www.nytimes.com/2015/09/25/us/pope-francis-congressspeech.html?_r=0 [http://perma.cc/2EW6-5SW7] ("Sitting behind Francis were Vice President Joseph R. Biden Jr. and House Speaker John A. Boehner, both Catholics. Flanking the aisle at the front were Secretary of State John Kerry and Chief Justice John G. Roberts Jr., and not far behind them was Nancy Pelosi, the House Democratic leader, all Catholics.”) Id. (explaining that Associate Justice Anthony Kennedy was in attendance as well).

263. Id.

264. Dahlia Lithwick, Fates Worse Than Death, SLATE (July 14, 2015), http://www.slate.com/articles/news_and_politics/jurisprudence/2015/07/will_kennedy_overturn_the _death_penalty_his_views_on_solitary_confinement.html [http://perma.cc/4K5D-H63K]. See also William D. Blake, God Save This Honorable Court, The Huffington Post Blog (Mar. 25, 2013) (explaining that the writer is not too sure of Justice Kennedy's faith affecting his choices), http://www.huffingtonpost.com/william-d-blake/supreme-court-justices-religion_b_2951293.html [http://perma.cc/ZSM4-YMZQ] and William Blake, God Save This Honorable Court: Religion as a Source of Judicial Policy, Political Research Quarterly 814-26 (2012), http://journals.sagepub.com/doi/pdf/10.1177/1065912911421015 [http://perma.cc/P9TR-XWYW]. In this article, the author examines the effect of religion on U.S. Supreme Court votes in 11 issue areas plausibly connected to religious values. Catholic Justices vote in ways that more closely adhere to the teachings of the Catholic Church than do non-Catholic Justices even after controlling for ideology. Id.

265. Justice Gorsuch has since joined the Court, now comprised of nine Justices following the death of Justice Antonin Scalia.

266. Dahlia Lithwick, Will He or Won't He?, SLATE (May 26, 2017), http://www.slate.com/articles/news_and_politics/jurisprudence/2017/05/how_anthony_kennedy_s_r etirement_decision_became_a_battle_over_the_trump.html [http://perma.cc/HJ7W-WD2K]. 
the cries of the condemned, by knowing the system is broken but failing to do or say? What good are we as members of that society, looking through the accused, though warned again and again of the wrongfulness of their treatment? What good are we to continue to fail to see the evil, saying foolish things while laughing in sorrow's face? What good am I, if I just continue to turn my back while the condemned silently dies? ${ }^{267}$

267. DYLAN, supra note 1. 